\title{
Review
}

\section{Phytochemicals in Gynecological Cancer Prevention}

\author{
Marta Woźniak ${ }^{1}$, Rafał Krajewski ${ }^{2}$, Sebastian Makuch ${ }^{1}$ (D) and Siddarth Agrawal $1,2,3, *$ (D) \\ 1 Department of Pathology, Wroclaw Medical University, 50-368 Wroclaw, Poland; \\ marta1wozniak@wp.pl (M.W.); sebastian.mk21@gmail.com (S.M.) \\ 2 Department and Clinic of Internal Medicine, Occupational Diseases, Hypertension and Clinical Oncology, \\ Wroclaw Medical University, 50-556 Wroclaw, Poland; rafal.krajewski@umed.wroc.pl \\ 3 Department of Cancer Prevention and Therapy, Wroclaw Medical University, 50-556 Wroclaw, Poland \\ * Correspondence: siddarth@agrawal.pl
}

check for

updates

Citation: Woźniak, M.; Krajewski,

R.; Makuch, S.; Agrawal, S.

Phytochemicals in Gynecological

Cancer Prevention. Int. J. Mol. Sci.

2021, 22, 1219. https://doi.org/

$10.3390 /$ ijms22031219

Academic Editors: Sanjay

K. Srivastava and Sung-Hoon Kim

Received: 12 November 2020

Accepted: 25 January 2021

Published: 26 January 2021

Publisher's Note: MDPI stays neutral with regard to jurisdictional claims in published maps and institutional affiliations.

Copyright: (c) 2021 by the authors. Licensee MDPI, Basel, Switzerland. This article is an open access article distributed under the terms and conditions of the Creative Commons Attribution (CC BY) license (https:// creativecommons.org/licenses/by/ $4.0 /)$.

\begin{abstract}
Gynecological cancer confers an enormous burden among women worldwide. Accumulating evidence points to the role of phytochemicals in preventing cervical, endometrial, and ovarian cancer. Experimental studies emphasize the chemopreventive and therapeutic potential of plant-derived substances by inhibiting the early stages of carcinogenesis or improving the efficacy of traditional chemotherapeutic agents. Moreover, a number of epidemiological studies have investigated associations between a plant-based diet and cancer risk. This literature review summarizes the current knowledge on the phytochemicals with proven antitumor activity, emphasizing their effectiveness and mechanism of action in gynecological cancer.
\end{abstract}

Keywords: phytochemicals; gynecological cancers; anticancer

\section{Introduction}

Currently, there is a dynamic increase in the number of cancer cases around the world. A total of 18.1 million new cases were reported in 2018, of which nearly 10 million were fatal [1]. It is estimated that a prolonged human lifespan and limited access to highly specialized anticancer treatment will result in an increase in the number of new malignant tumor cases [2]. In order to mitigate this trend, it is postulated to change people's habits by promoting regular physical activity and a balanced diet [3]. Such an approach seems to be justified due to the fact that $90-95 \%$ of all cancer risk factors are environmental ones, of which 30-35\% are dietary [4]. Epidemiological, experimental, and clinical studies are currently underway around the world to identify those components of the daily diet that may affect both the growth and reduction of cancer risk. Similar research is also being performed on gynecological tumors. In 2018, a total of 1,300,000 women worldwide suffered from gynecological cancer; and almost 610,000 cases were fatal [1]. Presented epidemiological data indicate that female genital cancers are still a serious public health concern [1]. Various first-line treatment strategies are administered based on the tumor stage and cell type, but surgery and chemotherapy are the most frequently included [5]. Despite the significant therapeutic advances in recent years, the current therapeutic options for gynecological cancers are insufficient. Novel promising targeted agents with potential anticancer effects comprise of antiangiogenic agents, poly (ADP-ribose) polymerase (PARP) inhibitors, tumor-intrinsic signaling pathway inhibitors, selective estrogen receptor downregulators, and immune checkpoint inhibitors, which target the main causes responsible for cancer development [6]. High-risk human papillomaviruses (HR-HPVs) are considered as the main etiologic factors of female lower genital tract malignancies [7]. For this reason, HPV testing is an important part of gynecological cancer screening, and immunization against HPV using vaccines has been a major step forward towards gynecological cancer prevention [8]. The most common gynecological cancers are cervical cancer, endometrial cancer, and ovarian cancer. The aforementioned cancer types are frequently characterized by mutations in K-RAS, H-RAS, BRAF, PTEN and TP53 [9,10], among others, each 
of which might be dietary-dependent [11]. In recent years, there has been an increasing number of studies indicating the possible anticancer effects of individual dietary components, especially those of plant origin [5]. For this reason, the authors present the results of epidemiological, experimental, and clinical studies indicating the possibility of using a plant-based diet and its components in the prevention of gynecological cancer. The fundamental goal of this review was to discuss the clinical significance and possible benefits of phytochemicals in the chemoprevention of female reproductive system cancers.

\section{Chemoprevention}

Chemoprevention uses synthetic, natural, or biological chemicals in order to inhibit, delay, or reverse carcinogenesis [12]. The preventive method was first introduced by Sporn et al. [13] and among others, uses compounds derived from commonly used vegetables, fruit, and whole-grain products-so-called phytochemicals, which are chemically divided into polyphenols, terpenoids, and thiols (Table 1) [14,15]. Chemoprevention may play an important role in reducing the development of various types of cancer, as nearly $33 \%$ of them can be prevented by lifestyle changes, including diet [14].

A model chemopreventive compound is one that is safe to use, has a known mechanism of action, can be administered orally, and is characterized by high efficiency and a low production cost [105]. Thanks to such features, it is possible to use it widely in the prevention of many diseases, including cancer [106-108]. In vitro and in vivo studies have shown a wide range of anticancerogenic effects of phytochemicals. Some of them have an anti-inflammatory effect by limiting the secretion of cytokines by cells, e.g., IL-1, IL-6, IL-8, IL-12, TNF-alfa [109]. In turn, by inhibiting VEGFA or PI3/Akt, they prevent cells from developing angiogenesis, which determines the growth and further development of cancer [110]. What is more, most phytochemicals act as antioxidants, which by eliminating free oxygen radicals, protects the cell's genetic material from damage and possible carcinogenesis [111]. In addition to reducing the risk of cancer, compounds of plant origin can also influence its treatment by improving both the sensitivity of tumors to chemotherapeutics and their demonstrated in vitro cytotoxic effects [112,113].

Due to the experimentally proven anticancerogenic effects of the selected phytochemicals, research is currently underway to assess their possible use in cancer preventionincluding gynecological cancers. The further part of the paper presents and discusses phytochemicals, which, in our opinion, are the most crucial in the chemoprevention of the most common malignant tumors of female genital organs, i.e., cervical cancer, endometrial cancer, and ovarian cancer (Figure 1). 
Table 1. Phytochemicals in gynecological cancer prevention: classification, natural occurrence, and application.

\begin{tabular}{|c|c|c|c|c|c|c|c|}
\hline \multirow[b]{2}{*}{ Phytochemicals } & \multicolumn{3}{|c|}{ Classification } & \multirow[b]{2}{*}{ Natural Occurrence } & \multicolumn{3}{|c|}{ Application with References } \\
\hline & Group & Subgroup & Class & & $\begin{array}{c}\text { Cervical } \\
\text { Cancer }\end{array}$ & $\begin{array}{l}\text { Endometrial } \\
\text { Cancer }\end{array}$ & $\begin{array}{c}\text { Ovarian } \\
\text { Cancer }\end{array}$ \\
\hline Quercetin & Polyphenols & Flavonoids & Flavonols & \multirow{2}{*}{$\begin{array}{l}\text { Onion, kale, leek, broccoli, buckwheat, red grapes, } \\
\text { tea, apples }\end{array}$} & {$[16,17]$} & [18] & {$[19,20]$} \\
\hline Kaempferol & Polyphenols & Flavonoids & Flavonols & & [21] & [22] & [23] \\
\hline Rutin & Polyphenols & Flavonoids & Flavonols & Cpers, olives, buckwheat, asparagus & [24] & ND & ND \\
\hline Apigenin & Polyphenols & Flavonoids & Flavones & \multirow{2}{*}{$\begin{array}{l}\text { Clery, herbs, parsley, chamomile, rooibos tea, } \\
\text { capsicum pepper }\end{array}$} & [25] & [26] & [27] \\
\hline Luteolin & Polyphenols & Flavonoids & Flavones & & [17] & ND & [28] \\
\hline Genistein & Polyphenols & Flavonoids & Isoflavones & \multirow{2}{*}{ Soya, beans, chickpeas, alfalfa, peanuts } & [29] & [30] & [31] \\
\hline Daidzein & Polyphenols & Flavonoids & Isoflavones & & ND & [30] & [32] \\
\hline Naringenin & Polyphenols & Flavonoids & Flavanones & \multirow{2}{*}{ Citrus fruit } & [33] & [34] & ND \\
\hline Hesperitin & Polyphenols & Flavonoids & Flavanones & & [35] & {$[36]$} & [37] \\
\hline Anthocyanidins & Polyphenols & Flavonoids & - & $\begin{array}{c}\text { Red grapes, blueberries, cherries, strawberries, blackberries, } \\
\text { raspberries }\end{array}$ & [38] & ND & ND \\
\hline $\begin{array}{l}\text { Epigallocatechin } \\
\text { gallate (EGCG) }\end{array}$ & Polyphenols & Flavonoids & Flavan-3-ols tannins & Tea, chocolate, grapes & [39] & {$[40,41]$} & {$[42,43]$} \\
\hline Silibinin & Polyphenols & Flavonoids & Flavanolols & Milk thistle, red onions & [46] & [47] & [48] \\
\hline Gallic acid & Polyphenols & Phenolic acids & Hydrobenzoic acids & \multirow{3}{*}{$\begin{array}{l}\text { Blackberries, grape seed, pomegranate, raspberries, } \\
\text { tea, vanilla }\end{array}$} & [49] & ND & [50] \\
\hline Ellagic acid & Polyphenols & Phenolic acids & Hydrobenzoic acids & & {$[51,52]$} & [53] & [54] \\
\hline Vanillic acid & Polyphenols & Phenolic acids & Hydrobenzoic acids & & ND & [53] & ND \\
\hline Ferulic acid & Polyphenols & Phenolic acids & Hydroxycinnamic acids & \multirow{2}{*}{ Blueberries, cinnamon, coffee, kiwi fruit, plums, wheat bran } & [55] & ND & ND \\
\hline Caffeic acid & Polyphenols & Phenolic acids & Hydroxycinnamic acids & & {$[56]$} & {$[57,58]$} & [59] \\
\hline Curcumin & Polyphenols & Non-flavonoid polyphenols & Curcuminoids & Turmeric & {$[51,60]$} & [61] & [62] \\
\hline Cinnamic acid & Polyphenols & Non-flavonoid polyphenols & Stilbenes & \multirow{2}{*}{ Blueberries, grapes, peanuts, raspberries, wine } & [63] & ND & ND \\
\hline Resveratrol & Polyphenols & Non-flavonoid polyphenols & Stilbenes & & [64] & [65] & {$[66,67]$} \\
\hline Enterolactone & Polyphenols & Non-flavonoid polyphenols & Lignans & \multirow{2}{*}{ Grains, flaxseed, sesame seeds } & ND & [68] & [69] \\
\hline Sesamin & Polyphenols & Non-flavonoid polyphenols & Lignans & & [70] & ND & ND \\
\hline $\begin{array}{l}\text { +Alpha-, beta-, } \\
\text { gamma-carotene }\end{array}$ & Terpenoids & Carotenoid terpenoids & - & Carrots, kale, pumpkin, sweet potato & [71] & ND & {$[72,73]$} \\
\hline
\end{tabular}


Table 1. Cont.

\begin{tabular}{|c|c|c|c|c|c|c|c|}
\hline \multirow[b]{2}{*}{ Phytochemicals } & \multicolumn{3}{|c|}{ Classification } & \multirow[b]{2}{*}{ Natural Occurrence } & \multicolumn{3}{|c|}{ Application with References } \\
\hline & Group & Subgroup & Class & & $\begin{array}{l}\text { Cervical } \\
\text { Cancer }\end{array}$ & $\begin{array}{l}\text { Endometrial } \\
\text { Cancer }\end{array}$ & $\begin{array}{c}\text { Ovarian } \\
\text { Cancer }\end{array}$ \\
\hline Zeaxanthin & Terpenoids & Carotenoid terpenoids & - & Corn, eggs, kale, spinach, red pepper, pumpkin, oranges & [71] & ND & ND \\
\hline Lycopene & Terpenoids & Carotenoid terpenoids & - & Tomatoes watermelon, pink grapefruit, guava, papaya & {$[71,74]$} & ND & [75-77] \\
\hline Astaxanthin & Terpenoids & Carotenoid terpenoids & - & Salmon, shrimp, krill, crab & ND & ND & [78] \\
\hline Saponins & Terpenoids & Non-carotenoid terpenoids & - & Chickpeas, soya beans & [79] & [80] & [81] \\
\hline Perillyl alcohol & Terpenoids & Non-carotenoid terpenoids & - & Caraway seeds, cherries, mint & ND & ND & [82] \\
\hline Siosterol & Terpenoids & Non-carotenoid terpenoids & Phytosterols & \multirow{2}{*}{$\begin{array}{l}\text { Vegetable oils, cereal grains, nuts, shoots, seeds and their } \\
\text { oils, whole grains, legumes }\end{array}$} & [83] & ND & ND \\
\hline Stigmasterol & Terpenoids & Non-carotenoid terpenoids & Phytosterols & & ND & [84] & [85] \\
\hline Ursolic acid & Terpenoids & Non-carotenoid terpenoids & - & Apples, cranberries, peppermint, prunes, oregano, thyme & [86] & [87] & {$[88,89]$} \\
\hline $\begin{array}{l}\text { Ginkgolide and } \\
\text { bilobalide }\end{array}$ & Terpenoids & Non-carotenoid terpenoids & - & Ginkgo biloba & [90] & ND & [91] \\
\hline Isothiocyanates & Thiols & - & Glucosinolates & $\begin{array}{l}\text { Cruciferous vegetables such as asparagus, broccoli, Brussel } \\
\text { sprouts, cauliflower, horseradish, mustard, radish, sprouts }\end{array}$ & [92] & [93] & [94] \\
\hline Allicin & Thiols & - & Allylic sulfides & Garlic, leeks, onions & [95] & [96] & [97] \\
\hline Betaines & Others & - & - & Beetroot & [100] & ND & ND \\
\hline Capsaicin & Others & - & - & Chili & ND & ND & [101] \\
\hline Piperine & Others & - & - & Black peppers & [102] & ND & {$[103,104]$} \\
\hline
\end{tabular}




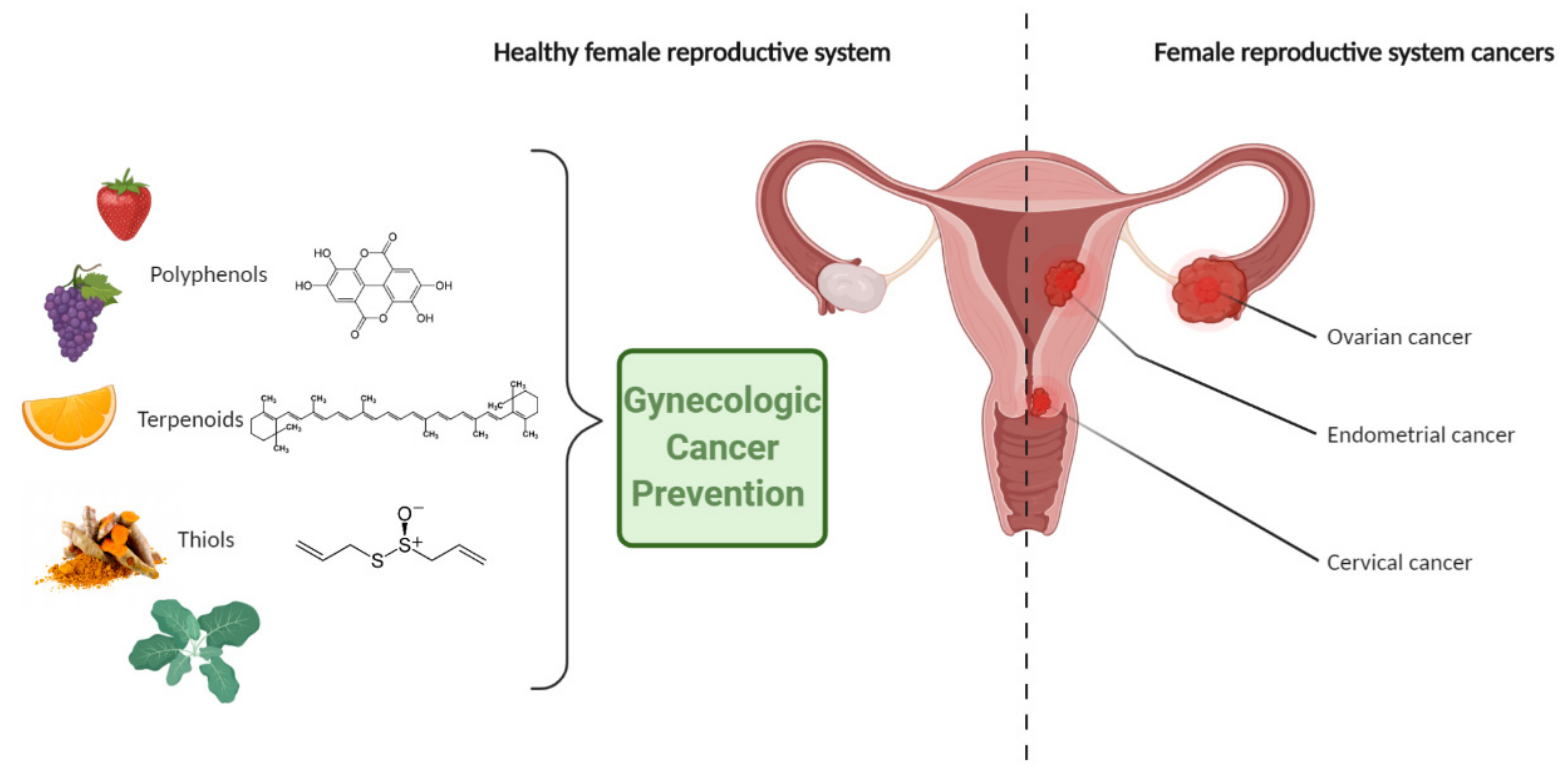

Figure 1. Polyphenols, terpenoids and thiols in gynecological cancer prevention.

\section{Phytochemicals in Cervical Cancer Prevention}

In the GLOBOCAN 2018 study, cervical cancer was ranked fourth in terms of both incidence $(569,847$ cases) and mortality $(311,365$ cases) from all cancers in the female population [1]. Its origin and development are strongly linked to the occurrence of the persistent infection of oncogenic strains of human papilloma virus (HPV) [114], in particular, HPV-16 and HPV-18 [21]. It is a DNA virus whose global prevalence is estimated at $11.7 \%$ [115]. Cytology, vaccination, and sex education are essential factors in limiting its spread in the population [116] and thus also reduce incidence and mortality due to cervical cancer [117]. Currently, more and more attention is also being paid to the possible influence of diet on the development of presented cancer $[118,119]$. Due to its anticancer action, plant-based compounds can play a special role in the prevention of various cancers, including cervical cancer [120].

\subsection{Polyphenols}

Numerous in vivo and/or in vitro studies indicate the anticancer effect of polyphenols [121], which is primarily based on the induction of apoptosis through various intracellular pathways. Convercetin - a flavonoid of onions, red grapes, broccoli, and apples-acts by increasing the concentration of the p53 protein and inhibiting the NF- $\mathrm{kB}$ pathway. [16]. Fisetin - a strawberry and cucumber flavonoid-activates enzymes from the caspase family 3 and 9 [122]. Naringin-grapefruit flavonoid-leads to cell death by the induction of death receptors [33]. Other mechanisms of action of polyphenols include the scavenging of free oxygen radicals, limiting cell proliferation, and reducing inflammation [123]. Experimental studies have shown that the following phytochemicals may be relevant among polyphenols in the chemoprevention of cervical cancer: kaempferol [21], rutin [24], gallic acid [49], ferulic acid [55], epigallocatechin gallate (EGCG) [39], curcumin [60], and caffeic acid [56]. This indicates significant potential for polyphenols in the chemoprevention of cervical cancer. Nevertheless, despite numerous experimental studies, there are currently few epidemiological studies available in the literature to verify their results. In an extensive cohort study, Gonzalez et al. investigated the correlation between different dietary factors and among others, the risk of invasive cervical cancer. It was observed that the consumption of fruit at a dose of $100 \mathrm{~g}$ /day was associated with a statistically significant reduction in the risk of invasive cervical cancer $(\mathrm{HR}=0.83,95 \% \mathrm{CI}=0.72-0.98)$. A similar relation 
was noted for vegetables, although it did not prove statistically significant $(\mathrm{HR}=0.85$, $95 \% \mathrm{CI}=0.65-1.10$ ) [124]. In addition, the meta-analysis of Tomita et al. (a total of 18 studies: 17 clinical control studies, one cohort study) showed that among women eating more fruit and vegetables, cervical cancer was 20 and $40 \%$ less frequent, respectively [125]. In the study by Barchitta et al., the authors showed that moderate adherence to the Mediterranean diet could reduce the risk of HPV infection compared to low adherence to it $(\mathrm{OR}=0.40$, $95 \% \mathrm{CI}=0.22-0.73$ ) [126]. The results of the study indicate the possibility of preventing cervical cancer by reducing the risk of infection with an oncogenic HPV strain.

\subsection{Terpenoides and Thioles}

Terpenoids include carotenoids, whose anticancerogenic value has been confirmed by experimental studies [127]. It seems that they may also be important in preventing the development of cervical cancer. Zhang et al. studied the relationship between the plasma concentrations of carotenoids, retinol, and tocopherol and the risk of cervical cancer among Chinese women. They proved that higher concentrations of carotenoids (alpha-carotene, betacarotene, lutein, zeaxanthin) and tocopherol (alpha-tocopherol) were associated with a lower risk of cervical cancer $(\mathrm{OR}=0.71,95 \% \mathrm{CI}=0.56-0.92, p=0.003 ; \mathrm{OR}=0.75,95 \% \mathrm{CI}=0.60-0.94$, $p=0.008$ respectively). In the same study, the authors demonstrated a statistically significant effect of individual carotenoids in reducing this risk for: alpha-carotenes $\mathrm{OR}=0.50$, $95 \% \mathrm{CI}=0.38-0.67, p<0.001$; beta-carotenes $\mathrm{OR}=0.70,95 \% \mathrm{CI}=0.56-0.88, p=0.002$; lutein and zeaxanthin $\mathrm{OR}=0.75,95 \% \mathrm{CI}=0.59-0.95, p=0.015$ [71]. Another compound from the group of terpenoids exhibiting anticancer effects is lycopene, which is found in tomatoes [128]. For cervical cancer cells, in vitro studies have shown that it can increase their sensitivity to cisplatin [74]. Other terpenoids with possible anticancer effects are ursolic acid [86] and ginkgolide B [90]. However, the results have not yet been confirmed by epidemiological studies. Among thiols, indole-3-carbinol (I3C) seems to be a promising chemopreventive compound, which can mainly be found in broccoli and Brussels sprouts. In vitro studies on cervical cancer cells have shown its anticancer effects [98]. The results were confirmed by a randomized, double-blind, multi-center clinical trial with a placebo assessing the effects and safety of 3,3'-diindolymethane (DIM, a stable form of I3C) for the treatment of cervical intraepithelial neoplasia (CIN). A total of 78 patients aged 18-39 years (56 out of 78 diagnosed with CIN I or CIN II) were included in this study. The research group applied DIM in the form of vaginal suppositories for 180 days. In the group of women receiving DIM at a dose of $200 \mathrm{mg} /$ day and $100 \mathrm{mg} /$ day, a $100 \%$ (CI 95\% $=82.35-100.00 \%)$ and $90.5 \%(C I 95 \%=69.62-98.83 \%)$ regression of CIN lesions on histological examination were observed, respectively. However, in the placebo group, only $61.1 \%$ of the patients had a regression of the lesions on histological examination (CI 95\% $=35.75-82.70 \%$ ) [129]. The presented results indicate a significant potential of I3C and its DIM derivative in the chemoprevention of cervical cancer. The allicin present in garlic and onion may also have an important preventive function for the analyzed type of cancer. In vitro studies have shown that reducing the expression of nuclear factor erythroid 2-related factor 2 leads to the death of cervical cancer cells [95].

\section{Phytochemicals in Endometrial Cancer Prevention}

In 2018, 382,096 new cases of endometrial cancer were reported worldwide, of which nearly 90,000 were fatal [1]. In terms of incidence, endometrial cancer ranks sixth among all female malignant cancers [1], and currently, the number of new cases is systematically increasing. This may be related to the obesity epidemic, which has doubled worldwide in less than 30 years [130]. This, in turn, is confirmed by the fact that $34 \%$ of all cases of endometrial cancer are related to a high body mass index (BMI) [130]. Compared to women with a BMI $<25 \mathrm{~kg} / \mathrm{m}^{2}$, women with BMI $>30 \mathrm{~kg} / \mathrm{m}^{2}$, BMI $<35 \mathrm{~kg} / \mathrm{m}^{2}$, and with BMI $>35 \mathrm{~kg} / \mathrm{m}^{2}$ had a 2.6- and 4.7-times higher risk of developing the disease, respectively [131]. This phenomenon may be explained, among others, by the high estrogen content in adipose tissue, which promotes the growth of the uterine mucosa [132]. Moreover, adipose tissue 
is the place of the secretion of adipokines, i.e., compounds of pro-inflammatory nature (e.g., IL-6, leptin) having the ability to induce pathways leading to consequent carcinogenesis. [132]. Obesity may be the consequence of an unbalanced diet, which in a two-fold way influences the risk of developing the analyzed cancer; a diet high in animal products may increase the risk of disease [133], while a diet rich in vegetables, fruit, or fish can reduce its risk [134]. The limiting effect of diet—especially a plant-based diet—on the development of endometrial cancer may be related to the anticancer effect of its individual components, including phytochemicals.

\subsection{Polyphenols}

Polyphenols include flavonoids-chemical compounds commonly found in vegetables and fruits-and their representatives include isoflavones such as genistein, daidzein, and glycitein [15]. It has been suggested that high doses of isoflavones show anti-estrogenic effects preventing the development of endometrial cancer [135]. A meta-analysis by Zhong et al. investigated the relationship between the consumption of isoflavones contained in soybean and legumes and the risk of endometrial cancer. The research included a total of 13 studies -3 cohort studies and 10 clinical control studies. The researchers found that compared to a lower isoflavone intake, its higher intake was associated with a $19 \%$ reduction in the risk of endometrial cancer (OR $=0.81,95 \% \mathrm{CI}=0.74-0.89)$. [136]. Such a reduced risk was also noted in the meta-analysis by Grosso et al. [137]. The possible chemopreventive effect of isoflavones was also evidenced by a cohort study by Ollberding et al., in which the authors showed that the consumption of isoflavones by women in the postmenopausal period was associated with a statistically significant $34 \%$ reduction in the risk of developing the disease $(\mathrm{RR}=0.66,95 \% \mathrm{CI}=0.47-0.91, p=0.02)$, while the consumption of individual isoflavone components, such as daidzein or genistein, was also associated with a statistically significant reduction in this risk by $36 \%(R R=0.64,95 \% C I=0.46-0.90, p=0.01)$ and $34 \%$ $(\mathrm{RR}=0.66,95 \% \mathrm{CI}=0.47-0.91, p=0.02)$, respectively [30]. In the same study, the authors estimated that in the research group of women, the risk of endometrial cancer can be reduced by $27 \%$ with a dose of isoflavones amounting to at least $7.82 \mathrm{mg}$ per $1000 \mathrm{kcal}$ per day. Isoflavone intake can reduce the growth of uterine mucosa and thus reduce the risk of developing endometrial cancer. The relationship between daily isoflavone intake and its effect on endometrial thickness was the subject of a meta-analysis of 23 randomized clinical trials by $\mathrm{Li}$ et al., who showed that daily isoflavone supplementation at a dose greater than $54 \mathrm{mg}$ can reduce endometrial thickness by $0.26 \mathrm{~mm}$ in postmenopausal women $(p=0.007)$. Moreover, not all studies confirm the above dependence [138]. In addition to isoflavones, other compounds from the polyphenol group seem to be important in the chemoprevention of endometrial cancer. Such a compound is an ingredient of green tea-epigallocatechin gallate [15], which has a comprehensive anticancer effect [139]. One of them is to prevent angiogenesis by reducing the concentration of vascular endothelial growth factor A (VEGFA), which has been proven by both in vivo and in vitro studies on endometrial cancer cell lines [40]. This can be confirmed by a meta-analysis by Zhou et al. evaluating the correlation between the consumption of green and black tea and the risk of endometrial cancer. It has been proven that the daily consumption of one cup of green tea was associated with an $11 \%$ lower risk of developing endometrial cancer $(\mathrm{RR}=0.89,95 \% \mathrm{CI}=0.84-0.94)$. Nevertheless, a similar relationship has not been demonstrated to this extent for black tea $(R R=0.99$, $95 \% \mathrm{CI}=0.94-1.03$ ) [140]. Similar conclusions were also drawn in the meta-analysis by Butler et al. in which the researchers observed that the consumption of green tea was associated with a $23 \%$ reduction in the risk of endometrial cancer ( $\mathrm{OR}=0.78,95 \% \mathrm{CI}=0.62-0.98)$ [141] Although green tea owes its potential anticancer effect to various catechins, it seems that the analyzed epigallocatechin gallate, which accounts for $50-70 \%$ of their concentration, is largely responsible for this effect [142]. However, it is worth mentioning that some meta-analyses have not shown the relationship between tea consumption and endometrial cancer risk $[143,144]$. For this reason, other polyphenolic compounds with promising chemopreventive potential in endometrial cancer are still being sought. Current in vitro studies 
have shown that some of them (quercetin [18], kaempferol [22], resveratrol [145], and hesperidin [36]) inhibit the development of carcinogenesis by affecting intracellular transmission. The presented studies indicate the significant chemopreventive potential of polyphenols in endometrial cancer. This is also confirmed by a clinical control study by Gifkins et al., which showed that the consumption of products containing polyphenolic compounds reduces the risk of developing endometrial cancer $(\mathrm{OR}=0.62 ; 95 \% \mathrm{CI}=0.39-0.98)$ [146].

\subsection{Terpenoids and Thiols}

The Mediterranean diet (MD) largely consists of fruit and vegetables rich in phytochemicals belonging to terpenoids and thiols - carotene, lutein, zeaxanthin, lycopene, astaxanthin, phytosterols, or isothiocyanates [147,148]. As mentioned above, all of them may exhibit anticancer effects to varying degrees. For this reason, research is underway to assess the impact of the Mediterranean diet on cancer development, including endometrial cancer. One of them was a clinical control study by Ricceri et al. in which the authors showed that higher vegetable consumption, following the Mediterranean diet, which has a low content of pro-inflammatory compounds which is associated with a lower risk of developing endometrial cancer (respectively: OR fifth quintile vs. first quintile $=0.34$, $95 \% \mathrm{CI}=0.17-0.68 ; \mathrm{OR}=0.51,95 \% \mathrm{CI}=0.39-0.86 ; \mathrm{OR}$ fifth quintile vs. first quintile $=3.28$, $95 \% \mathrm{CI}=1.30-8.26$ ) [93]. Similar results were also obtained by Filomeno et al. (OR for high adhesion $\mathrm{MD}=0.43,95 \% \mathrm{CI}=0.34-0.56$ ) [134]. Nevertheless, in recent years, there have been several experimental studies exploring new directions in the search for effective phytochemicals in endometrial cancer chemoprevention. The first example is asparanin A, which is a saponin found in medical asparagus (Asparagus officinalis L). The plant contains numerous compounds showing various effects, including anticancerogenic ones [149]. Zhang et al. were the first to demonstrate in vitro on the Ishikawa cell line that asparanin A can limit the proliferation of endometrial cancer cells and induce their apoptosis [80]. Another example is ginsenosides [150], which are found in ginseng root (Panax ginseng C. A. Meyer). Jo et al. have shown in vitro on the cell line (HEC)-1A that 20(S)-protopanaxadiol (one of the ginsenosides) leads to the death of endometrial cancer cells by the induction of apoptosis [151]. Despite the promising results of experimental studies, more research is still necessary, especially on the epidemiological type, which would verify the presented results and assess their possible chemopreventive effects on endometrial cancer. In turn, the literature currently devotes much attention to coffee- the most widely consumed beverage in the world $[152,153]$, which owes its biological action to various compounds, such as caffeine, chlorogenic acid, cafestol, and kahweol. The last two compounds-cafestol, kahweol-belong to terpenoids [152,153], and it is to a large extent to these compounds that coffee owes its anticancerogenic properties [154], which have been confirmed by numerous studies assessing the relationship between coffee consumption and the risk of developing endometrial cancer. A meta-analysis of Lukic et al. included 12 cohort studies and eight clinical control studies. The authors observed that, compared to lower coffee intake, its higher level was connected with endometrial cancer prevention (total $\mathrm{RR}=0.74$, $95 \% \mathrm{CI}=0.68-0.81$; for cohort studies $\mathrm{RR}=0.78,95 \% \mathrm{CI}=0.71-0.85$; for clinical control studies $\mathrm{RR}=0.63,95 \% \mathrm{CI}=0.53-0.76$ ). In the same research, it was estimated that in cohort studies, drinking one cup of coffee per day was associated with a 3\% reduction in the risk of endometrial cancer $(95 \% \mathrm{CI}=2-4 \%$ ), and in clinical control studies with a $12 \%$ reduction (95\% CI $=5-18 \%$ ) [57]. Similar conclusions were reached by the Lafranconi et al., who reported a $20 \%$ reduction in the risk of the disease with the consumption of four and more cups of coffee a day ( $R R=0.80,95 \% \mathrm{CI}=0.72-0.89)$ and $24 \%$ for postmenopausal cancers $(\mathrm{RR}=0.76,95 \% \mathrm{CI}=0.69-0.83)$ [58]. A reversal relationship between coffee consumption and the risk of endometrial cancer was also noted by Poole et al. [152].

\section{Phytochemicals in Ovarian Cancer Prevention}

The GLOBOCAN 2018 study ranks ovarian cancer as fourth in terms of incidence and third in terms of mortality among female genital malignant tumors [1]. Recent epi- 
demiological data indicate a downward trend in morbidity and mortality due to ovarian cancer [155], which is probably due to the use of oral hormonal contraception-a recognized preventive factor for ovarian cancer [156-158]. Nevertheless, despite this seemingly optimistic trend, ovarian cancer still poses a great danger for women, as currently there are no effective screening tests that would allow for its early detection and treatment while improving the survival of this group of patients [159]. For this reason, the majority of patients are diagnosed too late when the disease is already in its advanced stage, and 5-year survival in such a situation decreases even to $29 \%$ [160]. In addition, the effectiveness of the standard treatment of ovarian cancer, including surgical procedures with subsequent chemotherapy, depends on many factors, including the severity of the tumor and its molecular profile [161,162], which undoubtedly have a significant impact on the further prognosis of the patients. As in the case of cervical and endometrial cancer, a possible relationship between the type of diet and the risk of its development is currently being sought in ovarian cancer [163-165]. Phytochemicals present in plants may play an important role in reducing the risk of ovarian cancer due to their anticancer properties [166-168].

\subsection{Polyphenols}

Among the polyphenols, curcumin, found in turmeric, seems to be a promising chemical compound. Kuttan et al. first demonstrated the anticancerogenic properties of this compound in an experimental study in $1985[169,170]$. Since then, intensive research on its possible use in medicine, including oncology, has begun. Currently, there are no epidemiological studies that would allow to assess the effect of curcumin on ovarian cancer chemoprevention in the human population. However, the results of experimental studies indicate the possibility of its use in improving the treatment of patients with this type of cancer, as curcumin, through its anti-inflammatory and antioxidant effects, can limit the process of carcinogenesis $[171,172]$. In addition, a study by Seo et al. showed that curcumin, by inhibiting the sarco/endoplasmic reticulum calcium ATPase (SERCA) proteins, causes a disturbance in the calcium homeostasis of tumor cells, thus contributing to the induction of their apoptosis [62]. Moreover, the studies indicate that curcumin may be used as a means to reduce the drug resistance of ovarian cancer cells $[173,174]$. However, despite the experimental demonstration of the importance of curcumin in the treatment of ovarian cancer, its use is currently limited due to the lack of clear results from human studies [175]. Another compound from the group of polyphenols, which, due to its mechanisms of action, can be used in the chemoprevention of ovarian cancer, is resveratrol. The main source of this phytochemical is grape peel and wine [15]. The anticancer action of resveratrol consists not only of the induction of apoptosis but also of the autophagocytosis of ovarian cancer cells $[66,67,176]$. In addition, in vivo mouse studies showed that after applying cisplatin for 48 hours and then resveratrol for 72 hours, the frequency of ovarian cancer cell proliferation was significantly reduced [67]. An interesting mechanism of resveratrol action is the inhibition of the GLUT1 glucose transporters and the restriction of glucose introduction into cancer cells, which limits their growth and directs them to the apoptosis pathway [145]. Despite the promising results of the experimental studies, the epidemiological studies to date do not confirm them. A meta-analysis by Kim et al. assessed the relationship between wine consumption and ovarian cancer risk. An analysis of 10 studies (three cohort studies and seven clinical control studies) did not show the association between wine consumption and a reduction in the risk of ovarian cancer $(\mathrm{OR}=1.13,95 \% \mathrm{CI}=0.92-1.38)$ [177]. However, the insufficient number of epidemiological studies assessing the effect of resveratrol on the risk of ovarian cancer does not allow to draw clear conclusions. Therefore, more such research is needed to confirm the results obtained from experimental studies. In recent years, the attention of scientists has been drawn to the catechins contained in green tea, and particularly their representative-epigallocatechin gallate. Catechins are one of the more researched groups of chemicals in cancer prevention, including ovarian cancer. A meta-analysis of seven cohort studies and 11 clinical control studies showed a statistically significant reduction in the risk of ovarian cancer among women with family history and 
tea consumption. $(\mathrm{RR}=0.86,95 \% \mathrm{CI}=0.76-0.96)$ [178]. Similar conclusions were obtained in the meta-analysis of Gao et al. ( $\mathrm{OR}=0.81,95 \% \mathrm{CI}=0.73-0.89, p<0.0001)$ [179]. It is worth mentioning that numerous epidemiological studies have shown a positive correlation between the consumption of green tea and the reduction in ovarian cancer risk [141,180,181]. The above is also confirmed by the results of experimental research indicating that inhibiting the pathway of transforming growth factor-beta (TGF-beta) catechins may reduce the ability of tumor cells to metastasize [182].

\subsection{Terpenoids}

Carotenoids are a group of compounds that originate from carrots, tomatoes, peaches, mangoes, broccoli, spinach, or lettuce. The most important representatives of this group are alpha- and beta-carotenes and lycopene [15]. Similar to other plant-based compounds, they may exhibit anticancerogenic effects against many types of cancers: cervical cancer [183], endometrial cancer [184], and breast cancer [185]. Currently, data on the use of alphaand beta-carotenes in the chemoprevention (or even treatment) of ovarian cancer are inconclusive. On the one hand, an older study based on a meta-analysis showed a $16 \%$ reduction in the risk of developing ovarian cancer in the case of an increased consumption of beta-carotene-rich products $(\mathrm{RR}=0.84,95 \% \mathrm{CI}=0.75-0.94)$ [72]. This can be confirmed by an experimental study by de Souz et al., who demonstrated in vitro that tropical Brazilian fruits such as Murici and tapereba containing, among others, alpha- and beta-carotenes, may have cytotoxic properties against ovarian cancer cells (including those resistant to platinum derivatives) manifesting themselves as cell cycle inhibition and the induction of their apoptosis [186]. On the other hand, a randomized analysis carried out by Guo et al. showed that beta-carotene may increase the risk of epithelial ovarian cancer, but it may also reduce the risk of developing tumors with a low malignant potential [187]. In view of the above, further research is needed to determine the clear effect of carotenoids on the development of ovarian cancer. A meta-analysis of Li et al. showed a 3.7\% reduction in the risk of developing ovarian cancer if women followed a diet including lycopene in the postmenopausal period $(\mathrm{OR}=0.963,95 \% \mathrm{CI}=0.859-1.080)$, although this relationship did not prove statistically significant [75]. However, experimental research provides promising results. Holzapfel et al. demonstrated in an in vivo study that lycopene can reduce the risk of ovarian cancer cell metastasis [76]. Another study has shown that in vitro lycopene, by increasing the concentration of Bax pro-apoptotic proteins and decreasing the concentration of Bcl2 antiapoptotic proteins, induced programmed ovarian cancer cell death [77]. In turn, lycopene applied at a dose of $200 \mathrm{mg} / \mathrm{kg}$ and $400 \mathrm{mg} / \mathrm{kg}$ significantly reduced the risk of ovarian cancer in vivo in laying hens $(p<0.010)$ [188]. It is also worth noting that the European Food Safety Authority has confirmed the safety of lycopene, which is now commonly used as a preservative [189]. The clinical significance of carotenoids may be demonstrated by the Eid et al. study, which investigated the effect of adding fucoxanthins (carotenoids) to anticancer treatment on the reversal of the drug resistance of various types of cancer, including ovarian cancer. Their results showed a significant correlation between the combination of fucoxanthin and doxorubicin (anticancer drug) and the reduction in cancer cell resistance to the applied treatment [73].

\subsection{Thiols}

Glucosinolates comprise a group of chemical compounds whose highest concentration can be found in cruciferous vegetables: white cabbage, red cabbage, savoy cabbage, and napa cabbage. The representatives of this group are thiocyanates, isothiocyanates, nitriles, and indoles [15]. Chemopreventive properties have been demonstrated in particular for isothiocyanates (phenylethyl isothiocyanate, PEITC) and indoles (indole-3-carbinol, I3C) [190]. Glucosinolates have an anticarcinogenic effect on many types of cancers [191], including lung cancer [192], endometrial cancer [193], and colorectal cancer [194]. With regard to ovarian cancer, scientific data indicate the promising potential of PEITC. A metaanalysis by Jiyi et al. showed a positive correlation between the consumption of cruciferous 
vegetables and a reduced risk of ovarian cancer $(R R=0.89,95 \% C I=0.81-0.99)$ [195]. Similar conclusions were drawn from a meta-analysis conducted by Chinese researchers, in which the analysis of clinical control studies showed a reduced risk of ovarian cancer when following a diet rich in cruciferous vegetables $(R R=0.84,95 \% \mathrm{CI}=0.75-0.94)$. However, no similar relationship was found in cohort studies $(R R=1.00,95 \% C I=0.85-1.11)$ [196]. In turn, experimental studies have shown that PEITC caused the apoptosis of ovarian cancer cells by inducing the formation of reactive oxygen species in such cells [197]. In another PEITC study, by blocking the mTOR-STAT3 pathway, PEITC reduced the ability of cancer cells to metastasize [94]. I turn, in the case of the simultaneous administration of PEITC and metformin, an increase in the sensitivity of cancer cells to cisplatin was observed [198]. This discovery may be important in the treatment of chemically resistant forms of ovarian cancer. Due to its molecular mechanisms of action, PEITC seems to be applicable not only in chemoprevention but also in the treatment of ovarian cancer. It is also noteworthy that in vitro and in vivo studies showed a good tolerance of healthy cells to the used phytochemical compound [199]. In the case of I3C, experimental studies have shown that through its active metabolites (3,3'-diindolylmethane), it blocks the epidermal growth factor receptor (EGFR), whose overexpression is observed in ovarian cancer, among others. The aforementioned inhibition leads to the intracellular blocking of signals allowing the cells to proliferate and invade $[99,200]$. This compound may also be important in limiting the growth of ovarian cancer [201]. Significantly, the addition of I3C and/or epigallocatechin gallate to the standard therapy (surgical treatment, taxa) of advanced stage III or IV ovarian cancer was associated with both an increase in the overall survival of the patients and a period free of disease progression compared to the absence of these compounds in therapy [202]. Currently, there are no epidemiological data confirming the experimentally proven effect of I3C in the prevention of ovarian cancer.

\section{Conclusions}

The anticancerogenic effect of phytochemicals on the development of gynecological cancers is currently the subject of many scientific studies (Table 1). Experimental studies carried out in vitro and in vivo indicate their significant potential to reduce the development of cervical, endometrial as well as ovarian cancer. Moreover, the results presented in the paper indicate that phytochemicals can exert their chemopreventive effects in two ways. On the one hand, they reduce the risk of cancer development by inhibiting the early stages of carcinogenesis, i.e., initiation and promotion. On the other hand, when included in standard chemotherapy, they increase the sensitivity of cancer cells to its effects and thus may limit the progression of cancer. However, epidemiological studies (clinical control and cohort studies) do not always confirm the results presented in experimental studies. The reason for this may be the applied dose of phytochemicals, their variable assimilability, varied metabolism, or a mechanism of action different from those presented in experimental studies. Additionally, it should be mentioned that apart from the benefits, there may also be several limitations associated with the use of phytochemicals, such as:

- Their ambiguous effect on chemoprevention;

- The lack of data indicating the optimal and toxic doses;

- The lack of data regarding their potential side effects;

- The lack of data evaluating their pharmacodynamic properties;

- Contradictory results regarding the molecular pathways related to their action.

Moreover, most epidemiological studies assess the overall impact of fruit and vegetable consumption on the development of various types of cancer. Plants are the source of many phytochemicals, and for this reason, it is not always possible to clearly determine which chemical compound has a significant anticancer effect. Nevertheless, it seems that phytochemicals have a significant preventive as well as therapeutic potential regarding gynecological cancers. For this reason, the consumption of larger quantities of vegetables, fruit, and whole-grain products should be a recommended action for the prevention of cancers, including gynecological ones. 
Author Contributions: Conceptualization, M.W. and S.A.; methodology, M.W.; writing-original draft preparation, R.K.; writing-review and editing, M.W and S.M.; visualization, S.M.; funding acquisition, M.W. All authors have read and agreed to the published version of the manuscript.

Funding: This research was funded by Wroclaw Medical University, grant number STM.A010.20.135.

Institutional Review Board Statement: Not applicable.

Informed Consent Statement: Not applicable.

Data Availability Statement: Not applicable.

Conflicts of Interest: The authors declare no conflict of interest.

$\begin{array}{ll}\text { Abbreviations } \\ \text { VEGFA } & \text { Vascular endothelial growth factor A } \\ \text { HPV } & \text { Human papilloma virus } \\ \text { EGCG } & \text { Epigallocatechin gallate } \\ \text { CIN } & \text { Cervical intraepithelial neoplasia } \\ \text { DIM } & 3,3^{\prime} \text {-diindolymethane } \\ \text { SERCA } & \text { Sarco/endoplasmic reticulum calcium ATPase } \\ \text { TGF-beta } & \text { transforming growth factor-beta } \\ \text { PEITC } & \text { phenylethyl isothiocyanate } \\ \text { EGFR } & \text { Epidermal growth factor receptor }\end{array}$

\section{References}

1. Bray, F.; Ferlay, J.; Soerjomataram, I.; Siegel, R.L.; Torre, L.A.; Jemal, A. Global cancer statistics 2018: GLOBOCAN estimates of incidence and mortality worldwide for 36 cancers in 185 countries. CA Cancer J. Clin. 2018, 68, 394-424. [CrossRef] [PubMed]

2. Miller, K.D.; Nogueira, L.; Mariotto, A.B.; Rowland, J.H.; Yabroff, K.R.; Alfano, C.M.; Jemal, A.; Kramer, J.L.; Siegel, R.L. Cancer treatment and survivorship statistics, 2019. CA Cancer J. Clin. 2019, 69, 363-385. [CrossRef] [PubMed]

3. Kerr, J.; Anderson, C.; Lippman, S.M. Physical activity, sedentary behaviour, diet, and cancer: An update and emerging new evidence. Lancet Oncol. 2017, 18, e457-e471. [CrossRef]

4. Baena Ruiz, R.; Salinas Hernández, P. Cancer chemoprevention by dietary phytochemicals: Epidemiological evidence. Maturitas 2016, 94, 13-19. [CrossRef] [PubMed]

5. Farrand, L.; Oh, S.W.; Song, Y.S.; Tsang, B.K. Phytochemicals: A multitargeted approach to gynecologic cancer therapy. BioMed Res. Int. 2014, 2014, 1-10. [CrossRef]

6. Wang, Q.; Peng, H.; Qi, X.; Wu, M.; Zhao, X. Targeted therapies in gynecological cancers: A comprehensive review of clinical evidence. Signal Transduct. Target. Ther. 2020, 5. [CrossRef]

7. de Maria, S.; Santoro, A.; Fuggetta, M.P.; Rocchetti, R.; Cottarelli, A.; Lanzilli, G.; Stiuso, P.; Angelico, G.; Spadola, S.; Franco Zannoni, G.; et al. A possible interplay between HR-HPV and stemness in tumor development: An in vivo investigation of CD133 as a putative marker of cancer stem cell in HPV18-infected KB cell line. Apmis 2020, 128, 637-646. [CrossRef]

8. Group, T.F.I.S. Quadrivalent Vaccine against Human Papillomavirus to Prevent High-Grade Cervical Lesions. N. Engl. J. Med. 2007, 356, 1915-1927.

9. Sonoda, K. Molecular biology of gynecological cancer (Review). Oncol. Lett. 2016, 11, 16-22. [CrossRef]

10. Zannoni, G.F.; Angelico, G.; Santoro, A. Aberrant non-canonical WNT pathway as key-driver of high-grade serous ovarian cancer development. Virchows Arch. 2020, 477, 321-322. [CrossRef]

11. Bittoni, M.A.; Fisher, J.L.; Weier, R. The Influence of Lifestyle Risk Factors on the Occurrence of Gynecological Cancers: A Review of the Evidence and Opportunities for Prevention and Management. Int. J. Cancer Stud. Res. 2015, S2, 01-08.

12. Steward, W.P.; Brown, K. Cancer chemoprevention: A rapidly evolving field. Br. J. Cancer 2013, 109, 1-7. [CrossRef] [PubMed]

13. Sporn, M.B. Approaches to Prevention of Epithelial Cancer during the Preneoplastic Period. Cancer Res. 1976, 36, 2699-2702. [PubMed]

14. Chen, H.; Liu, R.H. Potential Mechanisms of Action of Dietary Phytochemicals for Cancer Prevention by Targeting Cellular Signaling Transduction Pathways. J. Agric. Food Chem. 2018, 66, 3260-3276. [CrossRef]

15. Thomas, R.; Butler, E.; Macchi, F.; Williams, M. Phytochemicals in cancer prevention and management? Br. J. Med. Pract. 2015, 8,815 .

16. Sundaram, M.K.; Raina, R.; Afroze, N.; Bajbouj, K.; Hamad, M.; Haque, S.; Hussain, A. Quercetin modulates signaling pathways and induces apoptosis in cervical cancer cells. Biosci. Rep. 2019, 39, 720. [CrossRef]

17. Lin, T.H.; Hsu, W.H.; Tsai, P.H.; Huang, Y.T.; Lin, C.W.; Chen, K.C.; Tsai, I.H.; Kandaswami, C.C.; Huang, C.J.; Chang, G.D.; et al. Dietary flavonoids, luteolin and quercetin, inhibit invasion of cervical cancer by reduction of UBE2S through epithelialmesenchymal transition signaling. Food Funct. 2017, 8, 1558-1568. [CrossRef] 
18. Sak, K. Site-specific anticancer effects of dietary flavonoid quercetin. Nutr. Cancer 2014, 66, 177-193. [CrossRef]

19. Liu, Y.; Gong, W.; Yang, Z.Y.; Zhou, X.S.; Gong, C.; Zhang, T.R.; Wei, X.; Ma, D.; Ye, F.; Gao, Q.L. Quercetin induces protective autophagy and apoptosis through ER stress via the p-STAT3/Bcl-2 axis in ovarian cancer. Apoptosis 2017, 22, 544-557. [CrossRef]

20. Gao, X.; Wang, B.; Wei, X.; Men, K.; Zheng, F.; Zhou, Y.; Zheng, Y.; Gou, M.; Huang, M.; Guo, G.; et al. Anticancer effect and mechanism of polymer micelle-encapsulated quercetin on ovarian cancer. Nanoscale 2012, 4, 7021-7030. [CrossRef]

21. Kashafi, E.; Moradzadeh, M.; Mohamadkhani, A.; Erfanian, S. Kaempferol increases apoptosis in human cervical cancer HeLa cells via PI3K/AKT and telomerase pathways. Biomed. Pharmacother. 2017, 89, 573-577. [CrossRef] [PubMed]

22. Chuwa, A.H.; Sone, K.; Oda, K.; Tanikawa, M.; Kukita, A.; Kojima, M.; Oki, S.; Fukuda, T.; Takeuchi, M.; Miyasaka, A.; et al. Kaempferol, a natural dietary flavonoid, suppresses $17 \beta$-estradiol-induced survivin expression and causes apoptotic cell death in endometrial cancer. Oncol. Lett. 2018, 16, 6195-6201. [CrossRef]

23. Luo, H.; Rankin, G.O.; Li, Z.; DePriest, L.; Chen, Y.C. Kaempferol induces apoptosis in ovarian cancer cells through activating p53 in the intrinsic pathway. Food Chem. 2011, 128, 513-519. [CrossRef] [PubMed]

24. Deepika, M.S.; Thangam, R.; Sheena, T.S.; Sasirekha, R.; Sivasubramanian, S.; Babu, M.D.; Jeganathan, K.; Thirumurugan, R. A novel rutin-fucoidan complex based phytotherapy for cervical cancer through achieving enhanced bioavailability and cancer cell apoptosis. Biomed. Pharmacother. 2019, 109, 1181-1195. [CrossRef] [PubMed]

25. Souza, R.P.; Bonfim-Mendonça, P.D.S.; Gimenes, F.; Ratti, B.A.; Kaplum, V.; Bruschi, M.L.; Nakamura, C.V.; Silva, S.O.; MariaEngler, S.S.; Consolaro, M.E.L. Oxidative Stress Triggered by Apigenin Induces Apoptosis in a Comprehensive Panel of Human Cervical Cancer-Derived Cell Lines. Oxid. Med. Cell. Longev. 2017, 2017, 1-18. [CrossRef]

26. Dean, M.; Austin, J.; Jinhong, R.; Johnson, M.E.; Lantvit, D.D.; Burdette, J.E. The Flavonoid Apigenin Is a Progesterone Receptor Modulator with In Vivo Activity in the Uterus. Horm. Cancer 2018, 9, 265-277. [CrossRef]

27. Tang, A.Q.; Cao, X.C.; Tian, L.; He, L.; Liu, F. Apigenin inhibits the self-renewal capacity of human ovarian cancer SKOV3-derived sphere-forming cells. Mol. Med. Rep. 2015, 11, 2221-2226. [CrossRef]

28. Liu, Q.; Zhu, D.; Hao, B.; Zhang, Z.; Tian, Y. Luteolin promotes the sensitivity of cisplatin in ovarian cancer by decreasing PRPA1-medicated autophagy. Cell. Mol. Biol. 2018, 64, 17-22. [CrossRef]

29. Hussain, A.; Harish, G.; Prabhu, S.A.; Mohsin, J.; Khan, M.A.; Rizvi, T.A.; Sharma, C. Inhibitory effect of genistein on the invasive potential of human cervical cancer cells via modulation of matrix metalloproteinase- 9 and tissue inhibitiors of matrix metalloproteinase-1 expression. Cancer Epidemiol. 2012, 36, 387-393. [CrossRef]

30. Ollberding, N.J.; Lim, U.; Wilkens, L.R.; Setiawan, V.W.; Shvetsov, Y.B.; Henderson, B.E.; Kolonel, L.N.; Goodman, M.T. Legume, soy, tofu, and isoflavone intake and endometrial cancer risk in postmenopausal women in the multiethnic cohort study. J. Natl. Cancer Inst. 2012, 104, 67-76. [CrossRef]

31. Ning, Y.; Feng, W.; Cao, X.; Ren, K.; Quan, M.; Chen, A.; Xu, C.; Qiu, Y.; Cao, J.; Li, X.; et al. Genistein inhibits stemness of SKOV3 cells induced by macrophages co-cultured with ovarian cancer stem-like cells through IL-8/STAT3 axis. J. Exp. Clin. Cancer Res. 2019, 38. [CrossRef] [PubMed]

32. Hua, F.; Li, C.H.; Chen, X.G.; Liu, X.P. Daidzein exerts anticancer activity towards SKOV3 human ovarian cancer cells by inducing apoptosis and cell cycle arrest, and inhibiting the Raf/MEK/ERK cascade. Int. J. Mol. Med. 2018, 41, 3485-3492. [CrossRef]

33. Ramesh, E.; Alshatwi, A.A. Naringin induces death receptor and mitochondria-mediated apoptosis in human cervical cancer (SiHa) cells. Food Chem. Toxicol. 2013, 51, 97-105. [CrossRef] [PubMed]

34. Aichinger, G.; Beisl, J.; Marko, D. The Hop Polyphenols Xanthohumol and 8-Prenyl-Naringenin Antagonize the Estrogenic Effects of Fusarium Mycotoxins in Human Endometrial Cancer Cells. Front. Nutr. 2018, 5, 5. [CrossRef] [PubMed]

35. Wang, Y.; Yu, H.; Zhang, J.; Gao, J.; Ge, X.; Lou, G. Hesperidin inhibits HeLa cell proliferation through apoptosis mediated by endoplasmic reticulum stress pathways and cell cycle arrest. BMC Cancer 2015, 15. [CrossRef] [PubMed]

36. Cincin, Z.B.; Kiran, B.; Baran, Y.; Cakmakoglu, B. Hesperidin promotes programmed cell death by downregulation of nongenomic estrogen receptor signalling pathway in endometrial cancer cells. Biomed. Pharmacother. 2018, 103, 336-345. [CrossRef] [PubMed]

37. Zhao, J.; Li, Y.; Gao, J.; De, Y. Hesperidin inhibits ovarian cancer cell viability through endoplasmic reticulum stress signaling pathways. Oncol. Lett. 2017, 14, 5569-5574. [CrossRef]

38. Pan, F.; Liu, Y.; Liu, J.; Wang, E. Stability of blueberry anthocyanin, anthocyanidin and pyranoanthocyanidin pigments and their inhibitory effects and mechanisms in human cervical cancer HeLa cells. RSC Adv. 2019, 9, 10842-10853. [CrossRef]

39. Wang, Y.Q.; Lu, J.L.; Liang, Y.R.; Li, Q.S. Suppressive effects of EGCG on cervical cancer. Molecules 2018, 23, 2334. [CrossRef]

40. Wang, J.; Man, G.C.W.; Chan, T.H.; Kwong, J.; Wang, C.C. A prodrug of green tea polyphenol (-)-epigallocatechin-3-gallate (Pro-EGCG) serves as a novel angiogenesis inhibitor in endometrial cancer. Cancer Lett. 2018, 412, 10-20. [CrossRef]

41. Manohar, M.; Fatima, I.; Saxena, R.; Chandra, V.; Sankhwar, P.L.; Dwivedi, A. (-)-Epigallocatechin-3-gallate induces apoptosis in human endometrial adenocarcinoma cells via ROS generation and p38 MAP kinase activation. J. Nutr. Biochem. 2013, 24, 940-947. [CrossRef] [PubMed]

42. Rao, S.D.; Pagidas, K. Epigallocatechin-3-gallate, a natural polyphenol, inhibits cell proliferation and induces apoptosis in human ovarian cancer cells. Anticancer Res. 2010, 30, 2519-2523.

43. Yan, C.; Yang, J.; Shen, L.; Chen, X. Inhibitory effect of Epigallocatechin gallate on ovarian cancer cell proliferation associated with aquaporin 5 expression. Arch. Gynecol. Obstet. 2012, 285, 459-467. [CrossRef] [PubMed]

44. Yu, H.C.; Chen, L.J.; Cheng, K.C.; Li, Y.X.; Yeh, C.H.; Cheng, J.T. Silymarin inhibits cervical cancer cell through an increase of phosphatase and tensin homolog. Phyther. Res. 2012, 26, 709-715. [CrossRef] [PubMed] 
45. Fan, L.; Ma, Y.; Liu, Y.; Zheng, D.; Huang, G. Silymarin induces cell cycle arrest and apoptosis in ovarian cancer cells. Eur. J. Pharmacol. 2014, 743, 79-88. [CrossRef]

46. Zhang, Y.; Ge, Y.; Chen, Y.; Li, Q.; Chen, J.; Dong, Y.; Shi, W. Cellular and molecular mechanisms of silibinin induces cell-cycle arrest and apoptosis on HeLa cells. Cell Biochem. Funct. 2012, 30, 243-248. [CrossRef]

47. Shi, Z.; Zhou, Q.; Gao, S.; Li, W.; Li, X.; Liu, Z.; Jin, P.; Jiang, J. Silibinin inhibits endometrial carcinoma via blocking pathways of STAT3 activation and SREBP1-mediated lipid accumulation. Life Sci. 2019, 217, 70-80. [CrossRef]

48. Cho, H.J.; Suh, D.S.; Moon, S.H.; Song, Y.J.; Yoon, M.S.; Park, D.Y.; Choi, K.U.; Kim, Y.K.; Kim, K.H. Silibinin inhibits tumor growth through downregulation of extracellular signal-regulated kinase and Akt in vitro and in vivo in human ovarian cancer cells. J. Agric. Food Chem. 2013, 61, 4089-4096. [CrossRef]

49. Zhao, B.; Hu, M. Gallic acid reduces cell viability, proliferation, invasion and angiogenesis in human cervical cancer cells. Oncol. Lett. 2013, 6, 1749-1755. [CrossRef]

50. He, Z.; Chen, A.Y.; Rojanasakul, Y.; Rankin, G.O.; Chen, Y.C. Gallic acid, a phenolic compound, exerts anti-angiogenic effects via the PTEN/AKT/HIF-1 $\alpha$ /VEGF signaling pathway in ovarian cancer cells. Oncol. Rep. 2016, 35, 291-297. [CrossRef]

51. Kumar, D.; Basu, S.; Parija, L.; Rout, D.; Manna, S.; Dandapat, J.; Debata, P.R. Curcumin and Ellagic acid synergistically induce ROS generation, DNA damage, p53 accumulation and apoptosis in HeLa cervical carcinoma cells. Biomed. Pharmacother. 2016, 81, 31-37. [CrossRef] [PubMed]

52. Guo, H.; Zhang, D.; Fu, Q. Inhibition of cervical cancer by promoting IGFBP7 expression using ellagic acid from pomegranate peel. Med. Sci. Monit. 2016, 22, 4881-4886. [CrossRef] [PubMed]

53. Bhavani, P.; Subramanian, P.; Kanimozhi, S. Preventive Efficacy of Vanillic Acid on Regulation of Redox Homeostasis, Matrix Metalloproteinases and Cyclin D1 in Rats Bearing Endometrial Carcinoma. Indian J. Clin. Biochem. 2017, 32, 429-436. [CrossRef] [PubMed]

54. Ceci, C.; Lacal, P.M.; Tentori, L.; De Martino, M.G.; Miano, R.; Graziani, G. Experimental evidence of the antitumor, antimetastatic and antiangiogenic activity of ellagic acid. Nutrients 2018, 10, 1756. [CrossRef]

55. Gao, J.; Yu, H.; Guo, W.; Kong, Y.; Gu, L.; Li, Q.; Yang, S.; Zhang, Y.; Wang, Y. The anticancer effects of ferulic acid is associated with induction of cell cycle arrest and autophagy in cervical cancer cells. Cancer Cell Int. 2018, 18. [CrossRef]

56. Chang, W.C.; Hsieh, C.H.; Hsiao, M.W.; Lin, W.C.; Hung, Y.C.; Ye, J.C. Caffeic Acid Induces Apoptosis in Human Cervical Cancer Cells Through the Mitochondrial Pathway. Taiwan. J. Obstet. Gynecol. 2010, 49, 419-424. [CrossRef]

57. Lukic, M.; Guha, N.; Licaj, I.; van den Brandt, P.A.; Stayner, L.T.; Tavani, A.; Weiderpass, E. Coffee Drinking and the Risk of Endometrial Cancer: An Updated Meta-Analysis of Observational Studies. Nutr. Cancer 2018, 70, 513-528. [CrossRef]

58. Lafranconi, A.; Micek, A.; Galvano, F.; Rossetti, S.; Del Pup, L.; Berretta, M.; Facchini, G. Coffee decreases the risk of endometrial cancer: A dose-response meta-analysis of prospective cohort studies. Nutrients 2017, 9, 1223. [CrossRef]

59. Gherman, C.; Braicu, O.L.; Zanoaga, O.; Jurj, A.; Pileczki, V.; Maralani, M.; Drigla, F.; Braicu, C.; Budisan, L.; Achimas-Cadariu, P.; et al. Caffeic acid phenethyl ester activates pro-apoptotic and epithelial-mesenchymal transition-related genes in ovarian cancer cells A2780 and A2780cis. Mol. Cell. Biochem. 2016, 413, 189-198. [CrossRef]

60. Singh, A.K.; Misra, K. Human papilloma virus 16 e6 protein as a target for curcuminoids, curcumin conjugates and congeners for chemoprevention of oral and cervical cancers. Interdiscip. Sci. Comput. Life Sci. 2013, 5, 112-118. [CrossRef]

61. Xu, H.; Gong, Z.; Zhou, S.; Yang, S.; Wang, D.; Chen, X.; Wu, J.; Liu, L.; Zhong, S.; Zhao, J.; et al. Liposomal Curcumin Targeting Endometrial Cancer Through the NF-кB Pathway. Cell. Physiol. Biochem. 2018, 48, 569-582. [CrossRef]

62. Seo, J.A.; Kim, B.; Dhanasekaran, D.N.; Tsang, B.K.; Song, Y.S. Curcumin induces apoptosis by inhibiting sarco/endoplasmic reticulum Ca2+ ATPase activity in ovarian cancer cells. Cancer Lett. 2016, 371, 30-37. [CrossRef] [PubMed]

63. Anantharaju, P.G.; Reddy, D.B.; Padukudru, M.A.; Chitturi, C.M.K.; Vimalambike, M.G.; Madhunapantula, S.R.V. Induction of colon and cervical cancer cell death by cinnamic acid derivatives is mediated through the inhibition of Histone Deacetylases (HDAC). PLoS ONE 2017, 12, e0186208. [CrossRef] [PubMed]

64. García-Zepeda, S.P.; García-Villa, E.; Díaz-Chávez, J.; Hernández-Pando, R.; Gariglio, P. Resveratrol induces cell death in cervical cancer cells through apoptosis and autophagy. Eur. J. Cancer Prev. 2013, 22, 577-584. [CrossRef]

65. Fukuda, T.; Oda, K.; Hiraike, O.W.; Sone, K.; Inaba, K.; Ikeda, Y.; Makii, C.; Miyasaka, A.; Kashiyama, T.; Tanikawa, M.; et al. Autophagy inhibition augments resveratrol-induced apoptosis in Ishikawa endometrial cancer cells. Oncol. Lett. 2016, 12, 2560-2566. [CrossRef] [PubMed]

66. Lang, F.; Qin, Z.; Li, F.; Zhang, H.; Fang, Z.; Hao, E. Apoptotic cell death induced by resveratrol is partially mediated by the autophagy pathway in human ovarian cancer cells. PLoS ONE 2015, 10. [CrossRef]

67. Tan, L.; Wang, W.; He, G.; Kuick, R.D.; Gossner, G.; Kueck, A.S.; Wahl, H.; Opipari, A.W.; Liu, J.R. Resveratrol inhibits ovarian tumor growth in an in vivo mouse model. Cancer 2016, 122, 722-729. [CrossRef] [PubMed]

68. Aarestrup, J.; Kyro, C.; Knudsen, K.E.B.; Weiderpass, E.; Christensen, J.; Kristensen, M.; Würtz, A.M.L.; Johnsen, N.F.; Overvad, K.; Tjonneland, A.; et al. Plasma enterolactone and incidence of endometrial cancer in a case-cohort study of Danish women. Br. J. Nutr. 2013, 109, 2269-2275. [CrossRef]

69. Liu, H.; Liu, J.; Wang, S.; Zeng, Z.; Li, T.; Liu, Y.; Mastriani, E.; Li, Q.H.; Bao, H.X.; Zhou, Y.J.; et al. Enterolactone has stronger effects than enterodiol on ovarian cancer. J. Ovarian Res. 2017, 10. [CrossRef]

70. Dou, H.; Yang, S.; Hu, Y.; Xu, D.; Liu, L.; Li, X. Sesamin induces ER stress-mediated apoptosis and activates autophagy in cervical cancer cells. Life Sci. 2018, 200, 87-93. [CrossRef] 
71. Zhang, Y.Y.; Lu, L.; Abliz, G.; Mijit, F. Serum carotenoid, retinol and tocopherol concentrations and risk of cervical cancer among chinese women. Asian Pacific J. Cancer Prev. 2015, 16, 2981-2986. [CrossRef] [PubMed]

72. Huncharek, M.; Kupelnick, B. Dietary fat intake and risk of epithelial ovarian cancer: A meta-analysis of 6,689 subjects from 8 observational studies. In Nutrition and Cancer; Taylor \& Francis: New York, NY, USA, 2001; Volume 40, pp. 87-91.

73. Eid, S.Y.; Althubiti, M.A.; Abdallah, M.E.; Wink, M.; El-Readi, M.Z. The carotenoid fucoxanthin can sensitize multidrug resistant cancer cells to doxorubicin via induction of apoptosis, inhibition of multidrug resistance proteins and metabolic enzymes. Phytomedicine 2020, 77, 153280. [CrossRef] [PubMed]

74. Aktepe, O.H.; Şahİn, T.K.; GÜner, G.; Arik, Z.; YalÇin, Ş. Lycopene sensitizes the cervical cancer cells to cisplatin via targeting nuclear factor-kappa B (NF-?B) pathway. Turk. J. Med. Sci. 2020. [CrossRef]

75. Li, X.; Xu, J. Meta-analysis of the association between dietary lycopene intake and ovarian cancer risk in postmenopausal women. Sci. Rep. 2014, 4. [CrossRef] [PubMed]

76. Holzapfel, N.P.; Shokoohmand, A.; Wagner, F.; Landgraf, M.; Champ, S.; Holzapfel, B.M.; Clements, J.A.; Hutmacher, D.W.; Loessner, D. Lycopene reduces ovarian tumor growth and intraperitoneal metastatic load. Am. J. Cancer Res. 2017, 7, 1322-1336.

77. $\mathrm{Xu}, \mathrm{J} . ; \mathrm{Li}, \mathrm{Y} . ; \mathrm{Hu}, \mathrm{H}$. Effects of lycopene on ovarian cancer cell line SKOV3 in vitro: Suppressed proliferation and enhanced apoptosis. Mol. Cell. Probes 2019, 46. [CrossRef]

78. Su, X.-Z.; Chen, R.; Wang, C.-B.; Ouyang, X.-L.; Jiang, Y.; Zhu, M.-Y. Astaxanthin Combine with Human Serum Albumin to Abrogate Cell Proliferation, Migration, and Drug-resistant in Human Ovarian Carcinoma SKOV3 Cells. Anticancer. Agents Med. Chem. 2019, 19, 792-801. [CrossRef]

79. Zhang, W.; Zhang, D.; Ma, X.; Liu, Z.; Li, F.; Wu, D. Paris saponin VII suppressed the growth of human cervical cancer Hela cells. Eur. J. Med. Res. 2014, 19, 41. [CrossRef]

80. Zhang, F.; Zhang, Y.Y.; Sun, Y.S.; Ma, R.H.; Thakur, K.; Zhang, J.G.; Wei, Z.J. Asparanin A from Asparagus officinalis L. Induces G0/G1 Cell Cycle Arrest and Apoptosis in Human Endometrial Carcinoma Ishikawa Cells via Mitochondrial and PI3K/AKT Signaling Pathways. J. Agric. Food Chem. 2020, 68, 213-224. [CrossRef]

81. Jia, L.Y.; Wu, X.J.; Gao, Y.; Rankin, G.O.; Pigliacampi, A.; Bucur, H.; Li, B.; Tu, Y.Y.; Chen, Y.C. Inhibitory effects of total triterpenoid saponins isolated from the seeds of the tea plant (camellia sinensis) on human ovarian cancer cells. Molecules 2017, 22, 1649. [CrossRef]

82. Song, X.; Liu, L.; Chang, M.; Geng, X.; Wang, X.; Wang, W.; Chen, T.C.; Xie, L.; Song, X. NEO212 induces mitochondrial apoptosis and impairs autophagy flux in ovarian cancer. J. Exp. Clin. Cancer Res. 2019, 38. [CrossRef] [PubMed]

83. Cheng, D.; Guo, Z.; Zhang, S. Effect of $\beta$-sitosterol on the expression of HPV E6 and p53 in cervical carcinoma cells. Wspolczesna Onkol. 2015, 19, 36-42. [CrossRef] [PubMed]

84. Liao, H.; Zhu, D.; Bai, M.; Chen, H.; Yan, S.; Yu, J.; Zhu, H.; Zheng, W.; Fan, G. Stigmasterol sensitizes endometrial cancer cells to chemotherapy by repressing Nrf2 signal pathway. Cancer Cell Int. 2020, 20, 480. [CrossRef] [PubMed]

85. Bae, H.; Song, G.; Lim, W. Stigmasterol causes ovarian cancer cell apoptosis by inducing endoplasmic reticulum and mitochondrial dysfunction. Pharmaceutics 2020, 12, 488. [CrossRef] [PubMed]

86. Wang, S.; Meng, X.; Dong, Y. Ursolic acid nanoparticles inhibit cervical cancer growth in vitro and in vivo via apoptosis induction. Int. J. Oncol. 2017, 50, 1330-1340. [CrossRef]

87. Achiwa, Y.; Hasegawa, K.; Udagawa, Y. Effect of ursolic acid on MAPK in cyclin D1 signaling and ring-type E3 ligase (SCF E3s) in two endometrial cancer cell lines. Nutr. Cancer 2013, 65, 1026-1033. [CrossRef]

88. Zhang, J.; Wang, W.; Qian, L.; Zhang, Q.; Lai, D.; Qi, C. Ursolic acid inhibits the proliferation of human ovarian cancer stem-like cells through epithelial-mesenchymal transition. Oncol. Rep. 2015, 34, 2375-2384. [CrossRef]

89. Wang, W.J.; Sui, H.; Qi, C.; Li, Q.; Zhang, J.; Wu, S.F.; Mei, M.Z.; Lu, Y.Y.; Wan, Y.T.; Chang, H.; et al. Ursolic acid inhibits proliferation and reverses drug resistance of ovarian cancer stem cells by downregulating ABCG2 through suppressing the expression of hypoxia-inducible factor- $1 \alpha$ in vitro. Oncol. Rep. 2016, 36, 428-440. [CrossRef]

90. Yiling, X.; Qingfeng, M.; Dejun, C.; Qing, Y.; Wei, Z. Effects of Ginkgolide B on the Proliferation and Apoptosis of Cervical Cancer Cells. Curr. Top. Nutraceutical Res. 2020, 18, 227-232. [CrossRef]

91. Ye, B.; Aponte, M.; Dai, Y.; Li, L.; Ho, M.C.D.; Vitonis, A.; Edwards, D.; Huang, T.N.; Cramer, D.W. Ginkgo biloba and ovarian cancer prevention: Epidemiological and biological evidence. Cancer Lett. 2007, 251, 43-52. [CrossRef]

92. Cheng, Y.M.; Tsai, C.C.; Hsu, Y.C. Sulforaphane, a dietary isothiocyanate, induces G2/M arrest in cervical cancer cells through cyclinB1 downregulation and GADD45ß/CDC2 association. Int. J. Mol. Sci. 2016, 17, 1530. [CrossRef] [PubMed]

93. Kristjansdottir, K.; Kim, K.; Choi, J.S.; Horan, T.C.; Brard, L.; Moore, R.G.; Singh, R.K. 7 Methyl indole ethyl isothiocyanate causes ROS mediated apoptosis and cell cycle arrest in endometrial cancer cells. Gynecol. Oncol. 2012, 126, 252-258. [CrossRef] [PubMed]

94. Shao, W.Y.; Yang, Y.L.; Yan, H.; Huang, Q.; Liu, K.J.; Zhang, S. Phenethyl isothiocyanate suppresses the metastasis of ovarian cancer associated with the inhibition of CRM1-mediated nuclear export and mTOR-STAT3 pathway. Cancer Biol. Ther. 2017, 18, 26-35. [CrossRef] [PubMed]

95. Zhang, Q.; Yang, D. Allicin suppresses the migration and invasion in cervical cancer cells mainly by inhibiting NRF2. Exp. Ther. Med. 2018. [CrossRef]

96. Ma, C.; Qin, Q.; Li, H.; Sun, H. Effect of Allicin on Tumor Tissue and Its Mechanism in Mice with Tumor-bearing Endometrial Carcinoma. Rev. Científica la Fac. Ciencias Vet. 2020, 30, 2324-2331. 
97. Xu, L.; Yu, J.; Zhai, D.; Zhang, D.; Shen, W.; Bai, L.; Cai, Z.; Yu, C. Role of JNK activation and mitochondrial Bax translocation in allicin-induced apoptosis in human ovarian cancer SKOV3 cells. Evid.-Based Complement. Altern. Med. 2014, 2014, 1-6. [CrossRef]

98. Chen, D.Z.; Qi, M.; Auborn, K.J.; Carter, T.H. Indole-3-carbinol and diindolylmethane induce apoptosis of human cervical cancer cells and in murine HPV16-transgenic preneoplastic cervical epithelium. J. Nutr. 2001, 131, 3294-3302. [CrossRef]

99. Dash, R.; Hosen, S.M.Z.; Karim, M.R.; Kabir, M.S.H.; Hossain, M.M.; Junaid, M.; Islam, A.; Paul, A.; Khan, M.A. In silico analysis of indole-3-carbinol and its metabolite DIM as EGFR tyrosine kinase inhibitors in platinum resistant ovarian cancer vis a vis ADME/T property analysis. J. Appl. Pharm. Sci. 2015, 5, 73-78. [CrossRef]

100. Guo, Y.; Xu, L.S.; Zhang, D.; Liao, Y.P.; Wang, H.P.; Lan, Z.H.; Guan, W.J.; Liu, C.Q. Betaine effects on morphology, proliferation, and p53-induced apoptosis of hela cervical carcinoma cells in vitro. Asian Pacific J. Cancer Prev. 2015, 16, 3195-3201. [CrossRef]

101. Arzuman, L.; Beale, P.; Chan, C.; Yu, J.Q.; Huq, F. Synergism from combinations of tris (benzimidazole) monochloroplatinum(II) chloride with Capsaicin, Quercetin, Curcumin and Cisplatin in human ovarian cancer cell lines. Anticancer Res. 2014, 34, 5453-5464.

102. Jafri, A.; Siddiqui, S.; Rais, J.; Ahmad, M.S.; Kumar, S.; Jafar, T.; Afzal, M.; Arshad, M. Induction of apoptosis by piperine in human cervical adenocarcinoma via ros mediated mitochondrial pathway and caspase-3 activation. EXCLI J. 2019, 18, 154-164. [PubMed]

103. Si, L.; Yang, R.; Lin, R.; Yang, S. Piperine functions as a tumor suppressor for human ovarian tumor growth via activation of JNK/p38 MAPK-mediated intrinsic apoptotic pathway. Biosci. Rep. 2018, 38. [CrossRef] [PubMed]

104. Pal, M.K.; Jaiswar, S.P.; Srivastav, A.K.; Goyal, S.; Dwivedi, A.; Verma, A.; Singh, J.; Pathak, A.K.; Sankhwar, P.L.; Ray, R.S. Synergistic effect of piperine and paclitaxel on cell fate via cyt-c, Bax/Bcl-2-caspase-3 pathway in ovarian adenocarcinomas SKOV-3 cells. Eur. J. Pharmacol. 2016, 791, 751-762. [CrossRef] [PubMed]

105. Meybodi, N.M.; Mortazavian, A.M.; Monfared, A.B.; Sohrabvandi, S.; Meybodi, F.A. Phytochemicals in cancer prevention: A review of the evidence. Int. J. Cancer Manag. 2017, 10, 7219.

106. Maru, G.B. Understanding the molecular mechanisms of cancer prevention by dietary phytochemicals: From experimental models to clinical trials. World J. Biol. Chem. 2016, 7, 88. [CrossRef] [PubMed]

107. Zhang, Y.J.; Gan, R.Y.; Li, S.; Zhou, Y.; Li, A.N.; Xu, D.P.; Li, H.B.; Kitts, D.D. Antioxidant phytochemicals for the prevention and treatment of chronic diseases. Molecules 2015, 20, 21138-21156. [CrossRef]

108. Bode, A.M.; Dong, Z. Toxic phytochemicals and their potential risks for human cancer. Cancer Prev. Res. 2015, 8, 1-8. [CrossRef]

109. Chen, C.Y.; Kao, C.L.; Liu, C.M. The cancer prevention, anti-inflammatory and anti-oxidation of bioactive phytochemicals targeting the TLR4 signaling pathway. Int. J. Mol. Sci. 2018, 19, 2729. [CrossRef]

110. Upadhyay, S.; Dixit, M. Role of polyphenols and other phytochemicals on molecular signaling. Oxid. Med. Cell. Longev. 2015, 2015, 1-15. [CrossRef]

111. Kotecha, R.; Takami, A.; Espinoza, J.L. Dietary phytochemicals and cancer chemoprevention: A review of the clinical evidence. Oncotarget 2016, 7, 52517-52529. [CrossRef]

112. Arora, I.; Sharma, M.; Tollefsbol, T.O. Combinatorial epigenetics impact of polyphenols and phytochemicals in cancer prevention and therapy. Int. J. Mol. Sci. 2019, 20, 4567. [CrossRef]

113. Singh, S.; Sharma, B.; Kanwar, S.S.; Kumar, A. Lead phytochemicals for anticancer drug development. Front. Plant Sci. 2016, 7, 7. [CrossRef]

114. Berman, T.A.; Schiller, J.T. Human papillomavirus in cervical cancer and oropharyngeal cancer: One cause, two diseases. Cancer 2017, 123, 2219-2229. [CrossRef]

115. Serrano, B.; Brotons, M.; Bosch, F.X.; Bruni, L. Epidemiology and burden of HPV-related disease. Best Pract. Res. Clin. Obstet. Gynaecol. 2018, 47, 14-26. [CrossRef]

116. Kessler, T.A. Cervical Cancer: Prevention and Early Detection. Semin. Oncol. Nurs. 2017, 33, 172-183. [CrossRef]

117. Ledford, L.R.C.; Lockwood, S. Scope and Epidemiology of Gynecologic Cancers: An Overview. Semin. Oncol. Nurs. 2019, 35, 147-150. [CrossRef]

118. Zhou, X.; Meng, Y. Association between serum folate level and cervical cancer: A meta-analysis. Arch. Gynecol. Obstet. 2016, 293, 871-877. [CrossRef]

119. Hwang, J.H.; Lee, J.K.; Kim, T.J.; Kim, M.K. The association between fruit and vegetable consumption and HPV viral load in high-risk HPV-positive women with cervical intraepithelial neoplasia. Cancer Causes Control 2010, 21, 51-59. [CrossRef]

120. Vanamala, J. Food systems approach to cancer prevention. Crit. Rev. Food Sci. Nutr. 2017, 57, 2573-2588. [CrossRef]

121. Wang, S.J.; Zheng, C.J.; Peng, C.; Zhang, H.; Jiang, Y.P.; Han, T.; Qin, L.P. Plants and cervical cancer: An overview. Expert Opin. Investig. Drugs 2013, 22, 1133-1156. [CrossRef]

122. Ying, T.H.; Yang, S.F.; Tsai, S.J.; Hsieh, S.C.; Huang, Y.C.; Bau, D.T.; Hsieh, Y.H. Erratum: Fisetin induces apoptosis in human cervical cancer HeLa cells through ERK1/2-mediated activation of caspase-8-/caspase-3-dependent pathway (Archives of Toxicology doi:10.1007/s00204-011-0754-6). Arch. Toxicol. 2012, 86, 823. [CrossRef]

123. Moga, M.A.; Dimienescu, O.G.; Arvatescu, C.A.; Mironescu, A.; Dracea, L.; Ples, L. The role of natural polyphenols in the prevention and treatment of cervical cancer-An overview. Molecules 2016, 21, 1055. [CrossRef] [PubMed]

124. González, C.A.; Travier, N.; Luján-Barroso, L.; Castellsagué, X.; Bosch, F.X.; Roura, E.; Bueno-De-Mesquita, H.B.; Palli, D.; Boeing, H.; Pala, V.; et al. Dietary factors and in situ and invasive cervical cancer risk in the European prospective investigation into cancer and nutrition study. Int. J. Cancer 2011, 129, 449-459. [CrossRef] [PubMed] 
125. Tomita, L.Y.; Horta, B.L.; da Silva, L.L.S.; Malta, M.B.; Franco, E.L.; Cardoso, M.A. Fruits and vegetables and cervical cancer: A systematic review and meta-analysis. Nutr. Cancer 2020, 1-13. [CrossRef] [PubMed]

126. Barchitta, M.; Maugeri, A.; Quattrocchi, A.; Agrifoglio, O.; Scalisi, A.; Agodi, A. The association of dietary patterns with high-risk human papillomavirus infection and cervical cancer: A cross-sectional study in Italy. Nutrients 2018, 10, 469. [CrossRef]

127. Ono, M.; Takeshima, M.; Nakano, S. Mechanism of the Anticancer Effect of Lycopene (Tetraterpenoids). Enzymes 2015, 37, 139-166. [PubMed]

128. Teodoro, A.J.; Oliveira, F.L.; Martins, N.B.; Maia, G.; de, A.; Martucci, R.B.; Borojevic, R. Effect of lycopene on cell viability and cell cycle progression in human cancer cell lines. Cancer Cell Int. 2012, 12. [CrossRef]

129. Ashrafian, L.; Sukhikh, G.; Kiselev, V.; Paltsev, M.; Drukh, V.; Kuznetsov, I.; Muyzhnek, E.; Apolikhina, I.; Andrianova, E. Double-blind randomized placebocontrolled multicenter clinical trial (phase IIa) on diindolylmethane's efficacy and safety in the treatment of CIN: Implications for cervical cancer prevention. EPMA J. 2015, 6. [CrossRef]

130. Lortet-Tieulent, J.; Ferlay, J.; Bray, F.; Jemal, A. International patterns and trends in endometrial cancer incidence, $1978-2013$. J. Natl. Cancer Inst. 2018, 110, 354-361. [CrossRef]

131. Shaw, E.; Farris, M.; McNeil, J.; Friedenreich, C. Obesity and endometrial cancer. Recent Results Cancer Res. 2016, $208,107-136$.

132. McDonald, M.E.; Bender, D.P. Endometrial Cancer: Obesity, Genetics, and Targeted Agents. Obstet. Gynecol. Clin. N. Am. 2019, 46, 89-105. [CrossRef]

133. Shivappa, N.; Hébert, J.R.; Rosato, V.; Rossi, M.; Montella, M.; Serraino, D.; La Vecchia, C. Dietary Inflammatory Index and Renal Cell Carcinoma Risk in an Italian Case-Control Study. Nutr. Cancer 2017, 69, 833-839. [CrossRef]

134. Rosato, V.; Guercio, V.; Bosetti, C.; Negri, E.; Serraino, D.; Giacosa, A.; Montella, M.; Vecchia, C.L.; Tavani, A. Mediterranean diet and colorectal cancer risk: A pooled analysis of three Italian case-control studies. Br. J. Cancer 2016, 115, 862-865. [CrossRef] [PubMed]

135. Křǐžová, L.; Dadáková, K.; Kašparovská, J.; Kašparovský, T. Isoflavones. Molecules 2019, 24, 1076. [CrossRef] [PubMed]

136. Zhong, X.S.; Ge, J.; Chen, S.W.; Xiong, Y.Q.; Ma, S.J.; Chen, Q. Association between Dietary Isoflavones in Soy and Legumes and Endometrial Cancer: A Systematic Review and Meta-Analysis. J. Acad. Nutr. Diet. 2018, 118, 637-651. [CrossRef] [PubMed]

137. Grosso, G.; Godos, J.; Lamuela-Raventos, R.; Ray, S.; Micek, A.; Pajak, A.; Sciacca, S.; D’Orazio, N.; Del Rio, D.; Galvano, F. A comprehensive meta-analysis on dietary flavonoid and lignan intake and cancer risk: Level of evidence and limitations. Mol. Nutr. Food Res. 2017, 61. [CrossRef] [PubMed]

138. Quaas, A.M.; Kono, N.; Mack, W.J.; Hodis, H.N.; Felix, J.C.; Paulson, R.J.; Shoupe, D. Effect of isoflavone soy protein supplementation on endometrial thickness, hyperplasia, and endometrial cancer risk in postmenopausal women: A randomized controlled trial. Menopause 2013, 20, 840-844. [CrossRef]

139. Almatrood, S.A.; Almatroudi, A.; Khan, A.A.; Alhumaydh, F.A.; Alsahl, M.A.; Rahmani, A.H. Potential therapeutic targets of epigallocatechin gallate (EGCG), the most abundant catechin in green tea, and its role in the therapy of various types of cancer. Molecules 2020, 25, 3146. [CrossRef]

140. Zhou, Q.; Li, H.; Zhou, J.G.; Ma, Y.; Wu, T.; Ma, H. Green tea, black tea consumption and risk of endometrial cancer: A systematic review and meta-analysis. Arch. Gynecol. Obstet. 2016, 293, 143-155. [CrossRef]

141. Butler, L.M.; Wu, A.H. Green and black tea in relation to gynecologic cancers. Mol. Nutr. Food Res. 2011, 55, 931-940. [CrossRef]

142. Khan, N.; Mukhtar, H. Tea polyphenols in promotion of human health. Nutrients 2019, 11, 39. [CrossRef]

143. Je, Y.; Park, T. Tea Consumption and Endometrial Cancer Risk: Meta-Analysis of Prospective Cohort Studies. Nutr. Cancer 2015, 67, 825-830. [CrossRef]

144. Yang, T.Y.O.; Crowe, F.; Cairns, B.J.; Reeves, G.K.; Beral, V. Tea and coffee and risk of endometrial cancer: Cohort study and meta-analysis. Am. J. Clin. Nutr. 2015, 101, 570-578. [CrossRef]

145. Rauf, A.; Imran, M.; Butt, M.S.; Nadeem, M.; Peters, D.G.; Mubarak, M.S. Resveratrol as an anti-cancer agent: A review. Crit. Rev. Food Sci. Nutr. 2018, 58, 1428-1447. [CrossRef]

146. Gifkins, D.; Olson, S.H.; Demissie, K.; Lu, S.E.; Kong, A.N.T.; Bandera, E.V. Total and individual antioxidant intake and endometrial cancer risk: Results from a population-based case-control study in New Jersey. Cancer Causes Control 2012, 23, 887-895. [CrossRef]

147. García-Pérez, C.A. Me gusta citar. Geotech. Geol. Earthq. Eng. 2016, 16, 129-145.

148. Maruca, A.; Catalano, R.; Bagetta, D.; Mesiti, F.; Ambrosio, F.A.; Romeo, I.; Moraca, F.; Rocca, R.; Ortuso, F.; Artese, A.; et al. The Mediterranean Diet as source of bioactive compounds with multi-targeting anti-cancer profile. Eur. J. Med. Chem. 2019, 181, 111579. [CrossRef]

149. Guo, Q.; Wang, N.; Liu, H.; Li, Z.; Lu, L.; Wang, C. The bioactive compounds and biological functions of Asparagus officinalis L.-A review. J. Funct. Foods 2020, 65, 103727. [CrossRef]

150. Chen, X.J.; Zhang, X.J.; Shui, Y.M.; Wan, J.B.; Gao, J.L. Anticancer Activities of Protopanaxadiol- and Protopanaxatriol-Type Ginsenosides and Their Metabolites. Evid.-Based Complement. Altern. Med. 2016, 2016, 1-19. [CrossRef] [PubMed]

151. Jo, H.; Jang, D.; Park, S.K.; Lee, M.G.; Cha, B.; Park, C.; Shin, Y.S.; Park, H.; Baek, J.M.; Heo, H.; et al. Ginsenoside 20(S)protopanaxadiol induces cell death in human endometrial cancer cells via apoptosis. J. Ginseng Res. 2021, 45, 126-133. [CrossRef]

152. Poole, R.; Kennedy, O.J.; Roderick, P.; Fallowfield, J.A.; Hayes, P.C.; Parkes, J. Coffee consumption and health: Umbrella review of meta-analyses of multiple health outcomes. BMJ 2017, 359, j5024. [CrossRef]

153. Saeidnia, S. Anticancer Terpenoids. In New Approaches to Natural Anticancer Drugs; Springer: Berlin, Germany, $2014 ;$ pp. 67-92. 
154. Hu, G.L.; Wang, X.; Zhang, L.; Qiu, M.H. The sources and mechanisms of bioactive ingredients in coffee. Food Funct. 2019, 10, 3113-3126. [CrossRef]

155. National Cancer Institute Surveillance. Epidemiology, and End Results: Prostate Cancer-Cancer Stat Facts; National Cancer Institute: Bethesda, MD, USA, 2020.

156. Stewart, C.; Ralyea, C.; Lockwood, S. Ovarian Cancer: An Integrated Review. Semin. Oncol. Nurs. 2019, 35, 151-156. [CrossRef]

157. Dungan, J.S. Ovarian cancer and oral contraceptives: Collaborative reanalysis of data from 45 epidemiological studies including 23257 women with ovarian cancer and 87303 controls. Yearb. Obstet. Gynecol. Women's Health 2009, 2009, 165-167. [CrossRef]

158. Iversen, L.; Fielding, S.; Lidegaard, Ø.; Mørch, L.S.; Skovlund, C.W.; Hannaford, P.C. Association between contemporary hormonal contraception and ovarian cancer in women of reproductive age in Denmark: Prospective, nationwide cohort study. BMJ 2018, 362, 3609. [CrossRef]

159. Coleman, R.L.; Hennessy, B.T.; Coleman, R.L.; Markman, M. Ovarian cancer Ovarian cancer. Crit. Rev. Oncol. Hematol. 2015, 6736, 433-440.

160. Reid, B.M.; Permuth, J.B.; Sellers, T.A. Epidemiology of ovarian cancer: A review. Cancer Biol. Med. 2017, 14, 9-32. [PubMed]

161. Narod, S. Can advanced-stage ovarian cancer be cured? Nat. Rev. Clin. Oncol. 2016, 13, 255-261. [CrossRef]

162. Rojas, V.; Hirshfield, K.M.; Ganesan, S.; Rodriguez-Rodriguez, L. Molecular characterization of epithelial ovarian cancer: Implications for diagnosis and treatment. Int. J. Mol. Sci. 2016, 17, 2113. [CrossRef]

163. Qiu, W.; Lu, H.; Qi, Y.; Wang, X. Dietary fat intake and ovarian cancer risk: A meta-analysis of epidemiological studies. Oncotarget 2016, 7, 37390-37406. [CrossRef]

164. Liu, J.; Tang, W.; Sang, L.; Dai, X.; Wei, D.; Luo, Y.; Zhang, J. Milk, yogurt, and lactose intake and ovarian cancer risk: A metaanalysis. Nutr. Cancer 2015, 67, 68-72. [CrossRef] [PubMed]

165. Hilliard, C. Comment on "Dairy, calcium, Vitamin D, and ovarian cancer risk in African-American women". Br. J. Cancer 2018, 119, 258-259. [CrossRef]

166. Khodavandi, A.; Alizadeh, F.; Razis, A.F.A. Association between dietary intake and risk of ovarian cancer: A systematic review and meta-analysis. Eur. J. Nutr. 2020. [CrossRef] [PubMed]

167. Playdon, M.C.; Nagle, C.M.; Ibiebele, T.I.; Ferrucci, L.M.; Protani, M.M.; Carter, J.; Hyde, S.E.; Neesham, D.; Nicklin, J.L.; Mayne, S.T.; et al. Pre-diagnosis diet and survival after a diagnosis of ovarian cancer. Br. J. Cancer 2017, 116, 1627-1637. [CrossRef] [PubMed]

168. Wang, H.F.; Yao, A.L.; Sun, Y.Y.; Zhang, A.H. Empirically derived dietary patterns and ovarian cancer risk: A meta-analysis. Eur. J. Cancer Prev. 2018, 27, 493-501. [CrossRef] [PubMed]

169. Kuttan, R.; Bhanumathy, P.; Nirmala, K.; George, M.C. Potential anticancer activity of turmeric (Curcuma longa). Cancer Lett. 1985, 29, 197-202. [CrossRef]

170. Storka, A.; Vcelar, B.; Klickovic, U.; Gouya, G.; Weisshaar, S.; Aschauer, S.; Bolger, G.; Helson, L.; Wolzt, M. Safety, tolerability and pharmacokinetics of liposomal curcumin in healthy humans. Int. J. Clin. Pharmacol. Ther. 2015, 53, 54-65. [CrossRef]

171. Hewlings, S.; Kalman, D. Curcumin: A Review of Its Effects on Human Health. Foods 2017, 6, 92. [CrossRef]

172. Perrone, D.; Ardito, F.; Giannatempo, G.; Dioguardi, M.; Troiano, G.; Lo Russo, L.; De Lillo, A.; Laino, L.; Lo Muzio, L. Biological and therapeutic activities, and anticancer properties of curcumin (Review). Exp. Ther. Med. 2015, 10, 1615-1623. [CrossRef]

173. Zhang, J.; Liu, J.; Xu, X.; Li, L. Curcumin suppresses cisplatin resistance development partly via modulating extracellular vesicle-mediated transfer of MEG3 and miR-214 in ovarian cancer. Cancer Chemother. Pharmacol. 2017, 79, 479-487. [CrossRef]

174. Gou, Q.; Liu, L.; Wang, C.; Wu, Q.; Sun, L.; Yang, X.; Xie, Y.; Li, P.; Gong, C. Polymeric nanoassemblies entrapping curcumin overcome multidrug resistance in ovarian cancer. Colloids Surfaces B Biointerfaces 2015, 126, 26-34. [CrossRef] [PubMed]

175. Bashang, H.; Tamma, S. The use of curcumin as an effective adjuvant to cancer therapy: A short review. Biotechnol. Appl. Biochem. 2020, 67, 171-179. [CrossRef] [PubMed]

176. Dybkowska, E.; Sadowska, A.; Świderski, F.; Rakowska, R.; Wysocka, K. The occurrence of resveratrol in foodstuffs and its potential for supporting cancer prevention and treatment. A review. Rocz. Panstw. Zakl. Hig. 2018, 69, 5-14. [PubMed]

177. Kim, H.S.; Kim, J.W.; Shouten, L.J.; Larsson, S.C.; Chung, H.H.; Kim, Y.B.; Ju, W.; Park, N.H.; Song, Y.S.; Kim, S.C.; et al. Wine drinking and epithelial ovarian cancer risk: A meta-analysis. J. Gynecol. Oncol. 2010, 21, 112-118. [CrossRef] [PubMed]

178. Zhan, X.; Wang, J.; Pan, S.; Lu, C. Tea consumption and the risk of ovarian cancer: A meta-analysis of epidemiological studies. Oncotarget 2017, 8, 37796-37806. [CrossRef] [PubMed]

179. Gao, M.; Ma, W.; Chen, X.B.; Chang, Z.W.; Zhang, X.D.; Zhang, M.Z. Meta-analysis of green tea drinking and the prevalence of gynecological tumors in women. Asia. Pac. J. Public Health 2013, 25, 43S-48S. [CrossRef]

180. Trudel, D.; Labbé, D.P.; Bairati, I.; Fradet, V.; Bazinet, L.; Têtu, B. Green tea for ovarian cancer prevention and treatment: A systematic review of the in vitro, in vivo and epidemiological studies. Gynecol. Oncol. 2012, 126, 491-498. [CrossRef]

181. Johnson, R.; Bryant, S.; Huntley, A.L. Green tea and green tea catechin extracts: An overview of the clinical evidence. Maturitas 2012, 73, 280-287. [CrossRef]

182. Sicard, A.A.; Dao, T.; Suarez, N.G.; Annabi, B. Diet-Derived Gallated Catechins Prevent TGF- $\beta$-Mediated Epithelial-Mesenchymal Transition, Cell Migration and Vasculogenic Mimicry in Chemosensitive ES-2 Ovarian Cancer Cells. Nutr. Cancer 2020, 1-12. [CrossRef]

183. Chih, H.J.; Lee, A.H.; Colville, L.; Binns, C.W.; Xu, D. A review of dietary prevention of human papillomavirus-related infection of the cervix and cervical intraepithelial neoplasia. Nutr. Cancer 2013, 65, 317-328. [CrossRef] 
184. Xu, W.H.; Dai, Q.; Xiang, Y.B.; Zhao, G.M.; Ruan, Z.X.; Cheng, J.R.; Zheng, W.; Shu, X.O. Nutritional factors in relation to endometrial cancer: A report from a population-based case-control study in Shanghai, China. Int. J. Cancer 2007, 120, 1776-1781. [CrossRef]

185. Hu, F.; Wang Yi, B.; Zhang, W.; Liang, J.; Lin, C.; Li, D.; Wang, F.; Pang, D.; Zhao, Y. Carotenoids and breast cancer risk: A meta-analysis and meta-regression. Breast Cancer Res. Treat. 2012, 131, 239-253. [CrossRef] [PubMed]

186. De Souza, V.R.; Brum, M.C.M.; Guimarães, I.D.S.; De Freitas Dos Santos, P.; Do Amaral, T.O.; Abreu, J.P.; Passos, T.; Freitas-Silva, O.; Gimba, E.R.P.; Teodoro, A.J. Amazon fruits inhibit growth and promote pro-apoptotic effects on human ovarian carcinoma cell lines. Biomolecules 2019, 9, 707. [CrossRef] [PubMed]

187. Guo, Y.; Lu, Y.; Jin, H. Appraising the role of circulating concentrations of micro-nutrients in epithelial ovarian cancer risk: A Mendelian randomization analysis. Sci. Rep. 2020, 10. [CrossRef] [PubMed]

188. Sahin, K.; Yenice, E.; Tuzcu, M.; Orhan, C.; Mizrak, C.; Ozercan, I.H.; Sahin, N.; Yilmaz, B.; Bilir, B.; Ozpolat, B.; et al. Lycopene Protects Against Spontaneous Ovarian Cancer Formation in Laying Hens. J. Cancer Prev. 2018, 23, 25-36. [CrossRef]

189. Liang, X.; Ma, C.; Yan, X.; Liu, X.; Liu, F. Advances in research on bioactivity, metabolism, stability and delivery systems of lycopene. Trends Food Sci. Technol. 2019, 93, 185-196. [CrossRef]

190. Kołodziejski, D.; Koss-Mikołajczyk, I.; Abdin, A.Y.; Jacob, C.; Bartoszek, A. Chemical Aspects of Biological Activity of Isothiocyanates and Indoles, the Products of Glucosinolate Decomposition. Curr. Pharm. Des. 2019, 25, 1717-1728. [CrossRef]

191. Singh, S.V.; Singh, K. Cancer chemoprevention with dietary isothiocyanates mature for clinical translational research. Carcinogenesis 2012, 33, 1833-1842. [CrossRef]

192. Wu, Q.J.; Xie, L.; Zheng, W.; Vogtmann, E.; Li, H.L.; Yang, G.; Ji, B.T.; Gao, Y.T.; Shu, X.O.; Xiang, Y.B. Cruciferous vegetables consumption and the risk of female lung cancer: A prospective study and a meta-analysis. Ann. Oncol. 2013, 24, 1918-1924. [CrossRef]

193. Bandera, E.V.; Kushi, L.H.; Moore, D.F.; Gifkins, D.M.; McCullough, M.L. Fruits and vegetables and endometrial cancer risk: A systematic literature review and meta-analysis. Nutr. Cancer 2007, 58, 6-21. [CrossRef]

194. Tse, G.; Eslick, G.D. Cruciferous vegetables and risk of colorectal neoplasms: A systematic review and meta-analysis. Nutr. Cancer 2014, 66, 128-139. [CrossRef]

195. Hu, J.; Hu, Y.; Hu, Y.; Zheng, S. Intake of cruciferous vegetables is associated with reduced risk of ovarian cancer: A meta-analysis. Asia Pac. J. Clin. Nutr. 2015, 24, 101-109. [PubMed]

196. Han, B.; Li, X.; Yu, T. Cruciferous vegetables consumption and the risk of ovarian cancer: A meta-analysis of observational studies. Diagn. Pathol. 2014, 9, 7. [CrossRef] [PubMed]

197. Hong, Y.H.; Uddin, M.H.; Jo, U.; Kim, B.; Song, J.; Suh, D.H.; Kim, H.S.; Song, Y.S. ROS accumulation by PEITC selectively kills ovarian cancer cells via UPR-mediated apoptosis. Front. Oncol. 2015, 5, 167. [CrossRef]

198. Soundararajan, P.; Kim, J.S. Anti-carcinogenic glucosinolates in cruciferous vegetables and their antagonistic effects on prevention of cancers. Molecules 2018, 23, 2983. [CrossRef] [PubMed]

199. Xiao, D.; Powolny, A.A.; Moura, M.B.; Kelley, E.E.; Bommareddy, A.; Kim, S.H.; Hahm, E.R.; Normolle, D.; Van Houten, B.; Singh, S.V. Phenethyl isothiocyanate inhibits oxidative phosphorylation to trigger reactive oxygen species-mediated death of human prostate cancer cells. J. Biol. Chem. 2010, 285, 26558-26569. [CrossRef]

200. Żołek, T.; Trzeciak, A.; Maciejewska, D. Theoretical evaluation of EGFR kinase inhibition and toxicity of di-indol-3-yl disulphides with anti-cancer potency. J. Biomol. Struct. Dyn. 2020, 1-13. [CrossRef]

201. Kandala, P.K.; Srivastava, S.K. Diindolylmethane-mediated Gli1 protein suppression induces anoikis in ovarian cancer cells in vitro and blocks tumor formation ability in vivo. J. Biol. Chem. 2012, 287, 28745-28754. [CrossRef]

202. Kiselev, V.I.; Ashrafyan, L.A.; Muyzhnek, E.L.; Gerfanova, E.V.; Antonova, I.B.; Aleshikova, O.I.; Sarkar, F.H. A new promising way of maintenance therapy in advanced ovarian cancer: A comparative clinical study. BMC Cancer 2018, 18. [CrossRef] 